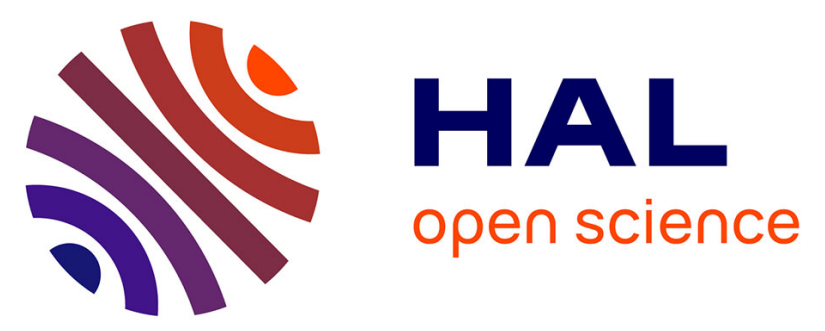

\title{
Unexpected Trends in the Stability and Dissociation Kinetics of Lanthanide(III) Complexes with Cyclen-Based Ligands across the Lanthanide Series
}

Zoltán Garda, Viktória Nagy, Aurora Rodríguez-Rodríguez, Rosa

Pujales-Paradela, Véronique Patinec, Goran Angelovski, Éva Tóth, Ferenc

Kálmán, David Esteban-Gómez, Raphaël Tripier, et al.

\section{To cite this version:}

Zoltán Garda, Viktória Nagy, Aurora Rodríguez-Rodríguez, Rosa Pujales-Paradela, Véronique Patinec, et al.. Unexpected Trends in the Stability and Dissociation Kinetics of Lanthanide(III) Complexes with Cyclen-Based Ligands across the Lanthanide Series. Inorganic Chemistry, 2020, 59

(12), pp.8184-8195. 10.1021/acs.inorgchem.0c00520 . hal-02564517

\section{HAL Id: hal-02564517 \\ https://hal.univ-brest.fr/hal-02564517}

Submitted on 19 Nov 2020

HAL is a multi-disciplinary open access archive for the deposit and dissemination of scientific research documents, whether they are published or not. The documents may come from teaching and research institutions in France or abroad, or from public or private research centers.
L'archive ouverte pluridisciplinaire HAL, est destinée au dépôt et à la diffusion de documents scientifiques de niveau recherche, publiés ou non, émanant des établissements d'enseignement et de recherche français ou étrangers, des laboratoires publics ou privés. 


\title{
Unexpected Trends in the Stability and Dissociation Kinetics of Lan- thanide(III) Complexes with Cyclen-Based Ligands Across the Lan- thanide Series
}

\author{
Zoltán Garda, ${ }^{\dagger}$ Viktoria Nagy, ${ }^{\dagger}$ Aurora Rodríguez-Rodríguez, $* *$ Rosa Pujales-Paradela, ${ }^{*}$ Véronique \\ Patinec, ${ }^{\S}$ Goran Angelovski, ${ }^{\perp}$ Éva Tóth, ${ }^{\|}$Ferenc K. Kálmán, ${ }^{\dagger}$ David Esteban-Gómez, ${ }^{*}$ Raphaël Tri- \\ pier, ${ }^{\S}$ Carlos Platas-Iglesias, ${ }^{*}$ and Gyula Tircsó $*^{\dagger}$ \\ ${ }^{\dagger}$ Department of Physical Chemistry, Faculty of Science and Technology, University of Debrecen, Egyetem tér 1, H-4032 \\ Debrecen, Hungary. \\ * Centro de Investigacións Científicas Avanzadas and Departamento de Química, Facultade de Ciencias, Universidade da \\ Coruña, 15071 Coruña, Galicia, Spain. \\ $\S$ Université de Bretagne Occidentale, UMR-CNRS 6521, UFR des Sciences et Techniques, 6 avenue Victor le Gorgeu, C.S. \\ 93837, 29238 Brest Cedex 3, France \\ ${ }^{\perp}$ MR Neuroimaging Agents, Max Planck Institute for Biological Cybernetics, 72076 Tuebingen, Germany \\ ' Centre de Biophysique Moléculaire, UPR 4301, CNRS, Université d'Orléans, rue Charles Sadron, 45071 Orléans Cedex 2, \\ France
}

\begin{abstract}
We report a detailed study of the thermodynamic stability and dissociation kinetics of lanthanide complexes with two ligands containing a cyclen unit, a methyl group, a picolinate arm and two acetate pendant arms linked to two nitrogen atoms of the macrocycle either in cis $\left(1,4-\mathrm{H}_{3} \mathrm{DO} 2 \mathrm{APA}\right)$ or trans $\left(1,7-\mathrm{H}_{3} \mathrm{DO} 2 \mathrm{APA}\right)$ positions. The stability constants of the $\mathrm{Gd}^{3+}$ complexes with these two ligands are very similar, with $\log K_{\mathrm{GdL}}$ values of 16.98 and 16.33 for the complexes of 1,4- $\mathrm{H}_{3} \mathrm{DO} 2 \mathrm{APA}$ and 1,7- $\mathrm{H}_{3} \mathrm{DO} 2 \mathrm{APA}$, respectively. The stability constants of the complexes with 1,4- $\mathrm{H}_{3} \mathrm{DO} 2 \mathrm{APA}$ follow the usual trend, increasing from $\log K_{\mathrm{LaL}}=15.96$ to $\log K_{\mathrm{LuL}}=19.21$. However, the stability of [ $\left.\operatorname{Ln}(1,7-\mathrm{DO} 2 \mathrm{APA})\right]$ complexes decreases from $\log K=16.33$ for $\mathrm{Gd}^{3+}$ to 14.24 for $\mathrm{Lu}^{3+}$. The acid-catalyzed dissociation rates of the $\mathrm{Gd}^{3+}$ complexes differ by a factor of $\sim 15$, with rate constants $\left(k_{1}\right)$, of 1.42 and $23.5 \mathrm{M}^{-1} \mathrm{~s}^{-1}$ for [Gd(1,4-DO2APA)] and [Gd(1,7-DO2APA)]. This difference is magnified across the lanthanide series to reach a five orders of magnitude higher $k_{1}$ for [Yb(1,7- DO2APA)] $\left(1475 \mathrm{M}^{-1} \mathrm{~s}^{-1}\right)$ than for [Yb(1,4-DO2APA)] $\left(5.79 \times 10^{-3}\right.$ $\mathrm{M}^{-1} \mathrm{~s}^{-1}$ ). The acid-catalysed mechanism involves the protonation of a carboxylate group, followed by a cascade of proton-transfer events that result in the protonation of a nitrogen atom of the cyclen unit. DFT calculations suggest a correlation between the strength of the $\mathrm{Ln}-\mathrm{O}_{\text {carboxylate }}$ bonds and the kinetic inertness of the complex, with stronger bonds providing more inert complexes. The ${ }^{1} \mathrm{H}$ NMR resonance of the coordinated water molecule in the [Yb(1,7-DO2APA)] complex at $176 \mathrm{ppm}$ provides a sizeable chemical exchange saturation transfer (CEST) effect thanks to a slow water exchange rate $\left.(15.9 \pm 1.6) \times 10^{3} \mathrm{~s}^{-1}\right)$.
\end{abstract}

\section{INTRODUCTION}

Lanthanide complexes based on the macrocyclic $1,4,7,10$ tetraazacyclododecane (cyclen) containing different types and numbers of pendant arms were intensively investigated in the last decades due to the important medical and bioanalytical applications of their metal complexes. ${ }^{1,2}$ For example, gadolinium complexes of cyclen derivatives are currently used as contrast agents in magnetic resonance imaging (MRI) ${ }^{3}$ while analogous complexes with other lanthanide ions are currently being investigated as paramagnetic ${ }^{1} \mathrm{H}$ chemical exchange saturation transfer (paraCEST), ${ }^{4-6}{ }^{19} \mathrm{~F}^{7-9}$ and paraSHIFT ${ }^{10,11}$ MRI contrast agents. Furthermore, many lanthanide cyclen- based luminescent complexes have been developed for application as optical probes in optical imaging or in cellulo studies. ${ }^{12-15}$

Whatever the targeted medical or biomedical application of a lanthanide complex, the chelate must present a high stability to avoid the toxic effects associated to the dissociation of the complex in vivo. ${ }^{16,17}$ Nowadays it is widely recognised that a high kinetic inertness with respect to their dissociation is more important than a high thermodynamic stability of the complex. ${ }^{18,19}$ For instance, it has been shown that lanthanide complexes with cyclen derivatives containing four acetamide pendant arms are extremely inert, ${ }^{20}$ which allowed their safe in vivo application, ${ }^{21-23}$ in spite of their low thermodynamic 
stabilities compared with those of the carboxylate analogue DOTA. $^{20}$

We recently reported a series of ligands based on the cyclen platform functionalized with both acetate and picolinate pendant arms (Chart 1). The first member of this series to be investigated was $\mathrm{H}_{4} \mathrm{DO} 3 \mathrm{APA}$, which forms lanthanide complexes with thermodynamic stabilities and kinetic inertness clearly inferior to those of DOTA. ${ }^{24}$ More recently, we also reported the 1,4- $\mathrm{H}_{3} \mathrm{DO} 2 \mathrm{APA}$ and $1,7-\mathrm{H}_{3} \mathrm{DO} 2 \mathrm{APA}$ ligands, whose lanthanide complexes were shown to possess some dramatically different properties in spite of having identical donor sets. ${ }^{25}$ For instance, the exchange rate of the coordinated water molecule in $[\mathrm{Gd}(1,4-\mathrm{DO} 2 \mathrm{APA})]$ was found to be three orders of magnitude faster than that of [Gd(1,7-DO2APA)], which was attributed to the weak coordination of the innersphere water molecule in the former due to the capping bond effect. ${ }^{25-27}$ In subsequent works we also showed that $\mathrm{Y}^{3+}$ and $\mathrm{Gd}^{3+}$ complexes of regioisomeric pyclen-based ligands showed rather different thermodynamic stabilities and dissociation kinetics. ${ }^{28,29}$

Chart 1. Structures of the ligands discussed in this work.<smiles>O=C(O)CN1CCN(CC(=O)O)CCN(CC(=O)O)CN(CC(=O)O)CC1</smiles>

$\mathrm{H}_{4}$ DOTA

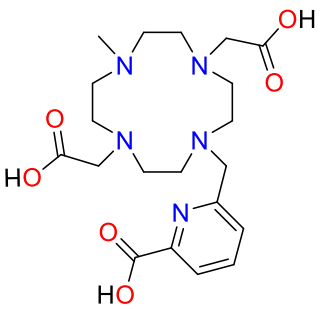

1,7- $\mathrm{H}_{3}$ DO2APA

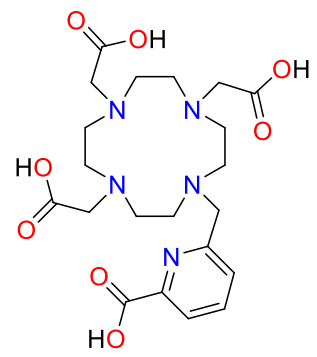

$\mathrm{H}_{4}$ DO3APA

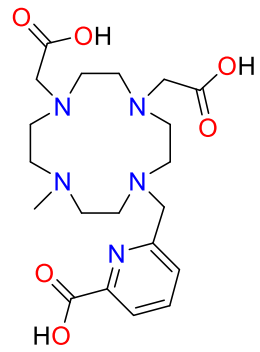

1,4- H $_{3}$ DO2APA
Given the very different exchange kinetics of the coordinated water molecules observed for the $\mathrm{Gd}^{3+}$ complexes of 1,4-DO2APA and 1,7-DO2APA, we sought to analyze whether the different arrangement of the ligand donor atoms around the $\mathrm{Ln}^{3+}$ ions also had an effect on the thermodynamic stability and dissociation kinetics of the complexes. Thus, herein we report protonation constants of the ligands and the stability constants of the metal complexes formed with several $\mathrm{Ln}^{3+}$ and divalent ions available in vivo $\left(\mathrm{Mg}^{2+}, \mathrm{Ca}^{2+}, \mathrm{Zn}^{2+}\right.$ and $\mathrm{Cu}^{2+}$ ). For this purpose, we employed a combination of potentiometric, relaxometric and spectrophotometric measurements. The dissociation kinetics of the $\mathrm{Ln}^{3+}$ complexes was investigated by following the exchange reactions of the correspond- ing complexes with $\mathrm{Cu}^{2+}$ at different $\mathrm{pH}$ values. A computational study was performed to gain insight at the molecular level into the trends observed across the lanthanide series. We will show for the first time that the rates of dissociation can vary dramatically across the lanthanide series, and that the different arrangement of the donor atoms around the metal ion may result in dissociation rates differing up to six orders of magnitude. Finally, we report paraCEST studies that provided the exchange rate of the coordinated water molecule in [Yb(1,7-DO2APA)].

\section{RESULTS AND DISCUSSION}

Ligand protonation constants. The protonation constants of 1,4-DO2 $\mathrm{APA}^{3-}$ and 1,7-DO2APA ${ }^{3-}$, defined as in eqn (1), were determined using $\mathrm{pH}$-potentiometric titrations in $0.15 \mathrm{M}$ $\mathrm{NaCl}$. The $\log K_{\mathrm{i}}^{\mathrm{H}}$ values are compared with those of DO3APA $^{4-}$ and DOTA ${ }^{4-}$ in Table $1 .^{24,30}$

$K_{i}^{H}=\frac{\left[\mathrm{H}_{i} \mathrm{~L}\right]}{\left[\mathrm{H}_{i-1} \mathrm{~L}\right]\left[\mathrm{H}^{+}\right]} \quad$ with $i=1,2, \ldots, 5$

The protonation constants of 1,4-DO2 $\mathrm{APA}^{3-}$ and $1,7-\mathrm{DO} 2 \mathrm{APA}^{3-}$ are very similar, as expected for two ligands having identical nature of their protonation sites. The first and second protonation processes are associated to two nitrogen atoms of the macrocycle in trans position, which allows a larger charge separation of the protonated sites. ${ }^{31}$ The remaining three protonation constants are attributed to the stepwise protonation of the three carboxylate groups of the ligand or additional $\mathrm{N}$ atoms of the macrocyclic unit. The first protonation constant is two $\log K$ units lower than that reported for DOTA $^{4-}$, which might be related, at least in part, to the higher negative charge of the latter. The total basicity $\left(2 \log K_{\mathrm{i}}^{\mathrm{H}}, \mathrm{i}=1\right.$ 4) of 1,4-DO2 $\mathrm{APA}^{3-}$ and 1,7-DO2 $\mathrm{APA}^{3-}$ is somewhat lower than that of DOTA $^{4-}$, but slightly higher than for DO3APA $^{3-}$ (Table 1). The values of the first protonation constants $\log K_{1}{ }^{\mathrm{H}}$ are significantly reduced on increasing the concentration of the background electrolyte from $0.15 \mathrm{M}$ to $1 \mathrm{M}$ $(\mathrm{NaCl})$, which can be attributed to the formation of relatively stable $\mathrm{Na}^{+}$complexes with these ligands. ${ }^{24}$

Stability constants of the metal complexes. The stability constants of the $\mathrm{Mg}^{2+}, \mathrm{Ca}^{2+}$ and $\mathrm{Zn}^{2+}$ complexes with 1,4-DO2 $\mathrm{APA}^{3-}$ and 1,7-DO2APA ${ }^{3-}$ were determined using direct $\mathrm{pH}$-potentiometric titrations. The stability constants are defined as in eqn (2), while the protonation constants of the complexes are expressed in eqn (3):

$K_{\mathrm{ML}}=\frac{[\mathrm{ML}]}{[\mathrm{M}][\mathrm{L}]}$

$K_{\mathrm{MH}_{i} \mathrm{~L}}=\frac{\left[\mathrm{MH}_{i} \mathrm{~L}\right]}{\left[\mathrm{MH}_{i-1} \mathrm{~L}\right]\left[\mathrm{H}^{+}\right]}$

The two ligands form rather weak complexes with $\mathrm{Mg}^{2+}$ and $\mathrm{Ca}^{2+}$, the corresponding stability constants being several orders of magnitude lower than those of DOTA $^{4-}$ and DO3APA ${ }^{4-}$ (Table 1). This comparison should be taken with caution due to the different ionic strengths used for stability constant determination. However, the $\mathrm{Zn}^{2+}$ complexes present 
thermodynamic stabilities comparable to those of the DOTA $^{4-}$ and DO3APA ${ }^{4-}$ analogues. It is noteworthy that the $\mathrm{Ca}^{2+}$ complex of 1,4-DO2 $\mathrm{APA}^{3-}$ is almost four orders of magnitude more stable than that of $1,7-\mathrm{DO} 2 \mathrm{APA}^{3-}$.

The stability constants of the $\mathrm{Cu}^{2+}$ complexes could not be determined by direct potentiometric titrations, as the formation of a protonated complex was quantitative at the beginning of the titrations at $\mathrm{pH} 1.7$. Thus, the formation of the complexes was followed by monitoring the changes of the $d$ - $d$ absorption bands of the metal/ligand systems as a function of proton concentration. At $\mathrm{pH} \sim 1$ the two systems present an absorption band in the visible spectrum at ca. $705 \mathrm{~nm}\left(\varepsilon=125 \mathrm{M}^{-1} \mathrm{~cm}^{-1}\right)$ whose intensity decreases upon increasing proton concentration (Fig. 1, see also Fig. S1, Supporting Information). Under these conditions, the absorption spectra are very similar to that measured for the $\mathrm{Cu}^{2+}: \mathrm{DO}^{3} \mathrm{~A}^{3-}$ system, ${ }^{32}$ suggesting that the diprotonated form of the complex dominates the solution speciation at this $\mathrm{pH}$ possesses a similar structure. In the case of $\left[\mathrm{Cu}\left(\mathrm{H}_{2} \mathrm{DOTA}\right)\right],{ }^{33}$ an X-ray structure evidenced coordination of the four nitrogen atoms of the macrocycle and two oxygen atoms of carboxylate groups, while the two uncoordinated arms are protonated.

Table 1. Ligand protonation constants as well as stability and protonation constants of metal complexes of 1,4-DO2APA ${ }^{3-}$ and $1,7-\mathrm{DO} 2 \mathrm{APA}^{3-}$ determined by $\mathrm{pH}$-potentiometry $\left(0.15 \mathrm{M} \mathrm{NaCl}, 25^{\circ} \mathrm{C}\right)$ and literature data for related systems.

\begin{tabular}{|c|c|c|c|c|c|}
\hline Metals / Ligand & & 1,4-DO2APA ${ }^{3-}$ & $1,7-\mathrm{DO} 2 \mathrm{APA}^{3-}$ & DO3APA $^{4, c}$ & DOTA $^{4-, d}$ \\
\hline & $\log K_{l}^{H}$ & $10.21(1) ; 9.44(5)^{e}$ & $10.15(2) ; 9.25(6)^{e}$ & 9.21 & 12.09 \\
\hline & $\log K_{2}{ }^{H}$ & $9.46(1) ; 9.55(2)^{e}$ & $9.26(2) ; 9.32(2)^{e}$ & 8.94 & 9.76 \\
\hline & $\log K_{3}{ }^{H}$ & $4.17(2) ; 4.19(5)^{e}$ & $4.22(2) ; 4.29(5)^{e}$ & 4.82 & 4.56 \\
\hline & $\log K_{4}^{H}$ & $3.65(3) ; 3.82(4)^{e}$ & $3.25(3) ; 3.49(4)^{e}$ & 3.52 & 4.09 \\
\hline & $\log K_{5}^{H}$ & $1.95(3) ; 1.95(3)^{e}$ & $2.38(3) ; 2.41(3)^{e}$ & 1.39 & - \\
\hline & $\sum \log K_{\mathrm{i}}^{\mathrm{H}}(i=1-4)$ & $27.49 ; 27.00^{e}$ & $26.88 ; 26.35^{e}$ & 26.49 & 30.50 \\
\hline \multirow[t]{4}{*}{$\mathrm{Mg}$} & $\log K_{\mathrm{MgL}}$ & $6.59(1)$ & $7.25(8)$ & 10.44 & 11.91 \\
\hline & $\log K_{\mathrm{MgHL}}$ & - & - & 6.89 & 3.92 \\
\hline & $\log K_{\mathrm{MgH} 2 \mathrm{~L}}$ & - & - & 6.37 & - \\
\hline & $\mathrm{pM}^{h}$ & 6.0 & 6.0 & 8.2 & 6.2 \\
\hline \multirow[t]{4}{*}{$\mathrm{Ca}$} & $\log K_{\mathrm{CaL}}$ & $12.72(1)$ & $8.96(7)$ & 14.82 & 17.23 \\
\hline & $\log K_{\mathrm{CaHL}}$ & $4.28(5)$ & - & 4.59 & 3.54 \\
\hline & $\log K_{\mathrm{CaH} 2 \mathrm{~L}}$ & - & - & 4.32 & 4.19 \\
\hline & $\mathrm{pM}^{h}$ & 8.8 & 6.1 & 12.4 & 11.1 \\
\hline \multirow[t]{5}{*}{$\mathrm{Cu}$} & $\log K_{\mathrm{CuL}}$ & $23.84(3)^{a, e}$ & $23.52^{a, e}$ & 23.20 & 22.25 \\
\hline & $\log K_{\mathrm{CuHL}}$ & $4.10(2)$ & $3.93(3)$ & 4.17 & 3.78 \\
\hline & $\log K_{\mathrm{CuH} 2 \mathrm{~L}}$ & $2.97(1)$ & $2.80(3)$ & 3.31 & 3.77 \\
\hline & $\log K_{\mathrm{CuH} 3 \mathrm{~L}}$ & - & - & 1.97 & - \\
\hline & $\mathrm{pM}^{h}$ & 19.9 & 19.9 & 20.8 & 16.2 \\
\hline \multirow[t]{5}{*}{$\mathrm{Zn}$} & $\log K_{\mathrm{ZnL}}$ & $19.36(4)$ & $20.23(4)$ & 20.25 & 21.09 \\
\hline & $\log K_{\mathrm{ZnHL}}$ & $3.92(3)$ & $3.55(3)$ & 4.42 & 4.18 \\
\hline & $\log K_{\mathrm{ZnH} 2 \mathrm{~L}}$ & $3.28(1)$ & $2.84(1)$ & 3.06 & 3.52 \\
\hline & $\log K_{\mathrm{ZnH} 3 \mathrm{~L}}$ & - & - & 1.98 & - \\
\hline & $\mathrm{pM}^{h}$ & 15.4 & 16.6 & 17.8 & 15.0 \\
\hline \multirow[t]{2}{*}{$\mathrm{La}$} & $\log K_{\mathrm{LaL}}$ & $15.96(1)$ & $15.26(1)$ & 21.17 & $21.7^{f}$ \\
\hline & $\begin{array}{l}\log K_{\mathrm{LaHL}} \\
\mathrm{pM}^{h}\end{array}$ & 12.0 & 11.6 & $\begin{array}{l}2.55 \\
18.8\end{array}$ & 15.6 \\
\hline Gd & $\log K_{\mathrm{GdL}}$ & $16.98(2), 17.12(2)^{b}$ & $\begin{array}{l}16.33(2)^{a} \\
16.69(2)^{b}\end{array}$ & 23.31 & $24.7^{f}, 25.3^{g}$ \\
\hline \multirow{5}{*}{$\mathrm{Lu}$} & $\log K_{\mathrm{GdHL}}$ & - & - & 2.65 & - \\
\hline & $\mathrm{pM}^{h}$ & 13.1 & 12.7 & 20.9 & 18.6 \\
\hline & $\log K_{\mathrm{LuL}}$ & $19.6(2), 19.21(2)^{b}$ & $\begin{array}{l}15.24(2)^{a}, \\
14.55(2)^{b}\end{array}$ & 22.82 & $25.4^{f}$ \\
\hline & $\log K_{\text {LuHL }}$ & - & - & 2.48 & - \\
\hline & $\mathrm{pM}^{h}$ & 15.7 & 11.6 & 20.4 & 19.3 \\
\hline
\end{tabular}

${ }^{a}$ Determined by simultaneous fitting of pH-potentiometric and UV-vis spectrophotometric data. ${ }^{b}$ Determined by ${ }^{1} \mathrm{H}$ relaxometry. ${ }^{c}$ Data in $0.1 \mathrm{M} \mathrm{KCl}$ from references 24 and 34. ${ }^{d}$ Data in $0.1 \mathrm{M} \mathrm{Me}_{4} \mathrm{NNO}_{3}$ from references 30 and $35 .{ }^{e}$ Data determined using a $1 \mathrm{M}$ $\left(\mathrm{c}_{\mathrm{HCl}}+\mathrm{c}_{\mathrm{NaCl}}\right)$ ionic strength. ${ }^{f}$ Data in $0.1 \mathrm{M} \mathrm{NaCl}$ from reference $38 .{ }^{g}$ Data from reference $39 .{ }^{h} \mathrm{pM}$ are defined as $-\log [\mathrm{M}]_{\text {free }}$ for $[\mathrm{M}]_{\mathrm{tot}}=1 \mu \mathrm{M}$ and $[\mathrm{L}]_{\mathrm{tot}}=10 \mu \mathrm{M}$. 


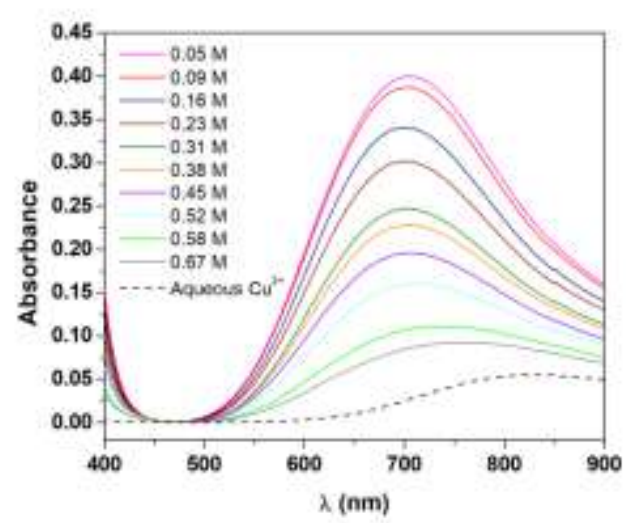

Figure 1. VIS spectra of the solutions containing nearly equimolar amounts of $\mathrm{Cu}^{2+}$ and 1,4-DO2APA ( $\mathrm{CCu}_{2}=2.99 \mathrm{mM}$, cLig=3.03 mM) as a function of acid concentration (see inset). The dashed spectrum corresponds to aqueous $\mathrm{Cu}^{2+}$ in $1.0 \mathrm{M} \mathrm{NaCl}$.

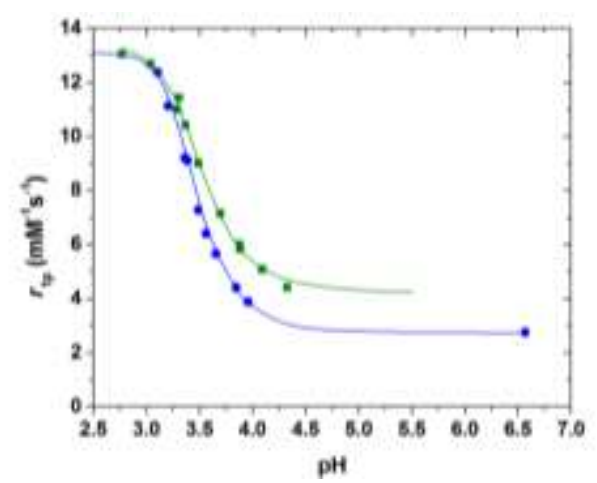

Figure 2. Relaxivity $\mathrm{pH}$ profiles of the equilibrated [Gd(1,4-DO2APA)] (squares) and [Gd(1,7-DO2APA)] (circles) complexes $\left([\mathrm{Gd}(\mathrm{L})]=1.5 \times 10^{-3} \mathrm{M}\right.$ normalized to $1.0 \times 10^{-3} \mathrm{M}, \mathrm{T}=$ $25{ }^{\circ} \mathrm{C}, I=0.15 \mathrm{M} \mathrm{NaCl}, \mathrm{B}=0.47 \mathrm{~T}$ ). The solid lines correspond to the fits of the data to obtain the stability constants given in Table 2 .

The simultaneous analysis of the spectroscopic and potentiometric data afforded the stability and protonation constants reported in Table 1 . The $\log K_{\mathrm{CuL}}$ values obtained for the complexes of 1,4-DO2 $\mathrm{APA}^{3-}$ and 1,7-DO2 $\mathrm{APA}^{3-}$ are slightly higher than those reported for DO3 $\mathrm{APA}^{4-34}$ and DOTA ${ }^{4-30,35}$ The corresponding $\mathrm{pM}$ values of the complexes containing picolinate groups are clearly higher than that calculated for the complex with DOTA ${ }^{4-}$. The speciation diagrams (Fig. S2-S8, Supporting Information) evidence the formation of protonated complex species below $\mathrm{pH} \sim 6$. Complex dissociation occurs only at rather acidic $\mathrm{pH}$ values $(<\mathrm{pH} \sim 3$ ).

The stability constants of representative $\mathrm{Ln}^{3+}$ complexes were obtained by using both $\mathrm{pH}$-potentiometry and the relaxometric technique $\left(\mathrm{Gd}^{3+}\right),{ }^{31}$ or by potentiometric titrations only $\left(\mathrm{La}^{3+}\right.$ and $\left.\mathrm{Lu}^{3+}\right)$. The relaxivity of the [Gd(1,4-DO2APA)] complex measured at $20 \mathrm{MHz}$ and $25^{\circ} \mathrm{C}(\mathrm{pH}=4.5)$ amounts to $r_{1 \mathrm{p}}=4.2$ $\mathrm{mM}^{-1} \mathrm{~s}^{-1}$, in good agreement with that reported previously. ${ }^{25}$ In the case of $[\mathrm{Gd}(1,7-\mathrm{DO} 2 \mathrm{APA})]$ the relaxivity measured in the same conditions $\left(r_{\mathrm{lp}}=2.7 \mathrm{mM}^{-1} \mathrm{~s}^{-1}\right)$ is somewhat higher than that measured previously without controlling the ionic strength $\left(r_{1 \mathrm{p}}=\right.$ $2.0 \mathrm{mM}^{-1} \mathrm{~s}^{-1}$ ). This is likely due to a faster water exchange of the coordinated water molecule in $0.15 \mathrm{M} \mathrm{NaCl}$, which is expected to increase the inner-sphere contribution to relaxivity. ${ }^{36}$ The relaxivities of the two complexes increase below $\mathrm{pH} 4.5$ reaching a value of $13.0 \mathrm{mM}^{-1} \mathrm{~s}^{-1}$ (Fig. 2) at $\mathrm{pH} \mathrm{3,} \mathrm{which} \mathrm{corresponds} \mathrm{to}$ the relaxivity of $\left[\mathrm{Gd}\left(\mathrm{H}_{2} \mathrm{O}\right)_{8}\right]^{3+} .{ }^{37}$ The analysis of the relaxivity data provided the stability constants of the two $\mathrm{Gd}^{3+}$ complexes, which turned out to be rather similar (Table 1). The stability constants determined using relaxometry and $\mathrm{pH}$-potentiometry are in good agreement. The stability constants determined for the $\mathrm{Gd}^{3+}$ complexes resulted to be six-seven orders of magnitude lower than that reported for $[\mathrm{Gd}(\mathrm{DO} 3 \mathrm{APA})]^{-24}$ and seven-eight orders of magnitude lower than the stability constants reported for $[\mathrm{Gd}(\mathrm{DOTA})]^{-38,39}$ This highlights the dramatic effect that removing one of the carboxylate groups of the ligand causes on the thermodynamic stability of the complexes. The stability constants of the complexes with 1,4-DO2 $\mathrm{APA}^{3-}$ increase across the lanthanide series from $\mathrm{La}^{3+}$ to $\mathrm{Lu}^{3+}$, with $\Delta \log K=$ $\log K_{\mathrm{LuL}}-\log K_{\mathrm{LaL}}=3.2$. This trend is observed for most lanthanide complexes as a consequence of the increasing charge density of the metal ion due to the lanthanide contraction. ${ }^{40}$

The stability constants of 1,4-DO2APA ${ }^{3-}$ complexes increases along the series, as usually observed for $\mathrm{Ln}^{3+}$ complexes. In contrast, the stability of the complexes with 1,7-DO2 $\mathrm{APA}^{3-}$ increases one order of magnitude from $\mathrm{La}^{3+}$ to $\mathrm{Gd}^{3+}$ and then decreases from $\mathrm{Gd}^{3+}$ to $\mathrm{Lu}^{3+}$. This stability trend is rather uncommon, though has been observed for the complexes of DTPA ${ }^{5-}{ }^{41}$ A fully reversed stability trend with the stability decreasing across the series was also observed for a few systems, and attributed to the weakening of some $\mathrm{Ln}^{3+}$-donor bonds due to steric constraints. ${ }^{42}$ As a result, a smaller increase of the overall electrostatic interaction between the ligand and the $\mathrm{Ln}^{3+}$ ion across the $4 \mathrm{f}$ period does not compensate the more negative hydration energies of the lanthanide ions. ${ }^{40}$

Dissociation kinetics. Both the free metal ion and the ligand released as a result of complex dissociation are potentially toxic (the former being more toxic), and thus metal-complexes for medical applications must have high kinetic inertness. The inertness of metal complexes with respect to dissociation is often assessed by measuring dissociation rates under acidic conditions, sometimes in the presence of $\mathrm{Zn}^{2+}$ or $\mathrm{Cu}^{2+}$ metal ions as ligand scavengers. Generally, the dissociation of $\mathrm{Gd}^{3+}$ complexes with cyclen-based ligands such as DOTA ${ }^{4-}$ or DO3A $\mathrm{A}^{3-}$ occurs slowly following the proton-assisted dissociation mechanism, while the presence of metal ions such as $\mathrm{Zn}^{2+}$ and $\mathrm{Cu}^{2+}$ in most of the cases does not affect the dissociation rates. ${ }^{43,44}$

The inertness of the [Ln(1,4-DO2APA) $]$ and [Ln(1,7-DO2APA $)]$ complexes $(\mathrm{Ln}=\mathrm{La}, \mathrm{Gd}$ or $\mathrm{Yb})$ was assessed by studying the rates of the metal exchange reactions occurring with $\mathrm{Cu}^{2+}$ ions (Eq 4$)$ at $25{ }^{\circ} \mathrm{C}$ by following the formation of the corresponding $\mathrm{Cu}^{2+}$ complex at $300 \mathrm{~nm}$ (Eq (4)).

$$
\mathrm{LnL}+\mathrm{Cu}^{2+} \leftrightarrows \mathrm{CuL}^{-}+\mathrm{Ln}^{3+}
$$

Where $\mathrm{L}$ denotes either the 1,4-DO2APA ${ }^{3-}$ or 1,7- DO2 $\mathrm{APA}^{3-}$ chelator. In the presence of 10-40 fold excess of the $\mathrm{Cu}^{2+}$-ion, the transmetallation reaction of the complexes can be treated as a pseudo-first-order process whose rate can be expressed by eqn (5): 


$$
-\frac{d[\mathrm{LnL}]_{t}}{d t}=k_{d}[\mathrm{LnL}]_{t}
$$

where $k_{\mathrm{d}}$ is a pseudo-first-order rate constant and $[\mathrm{LnL}]_{t}$ is the concentration of the LnL species at time $t$.

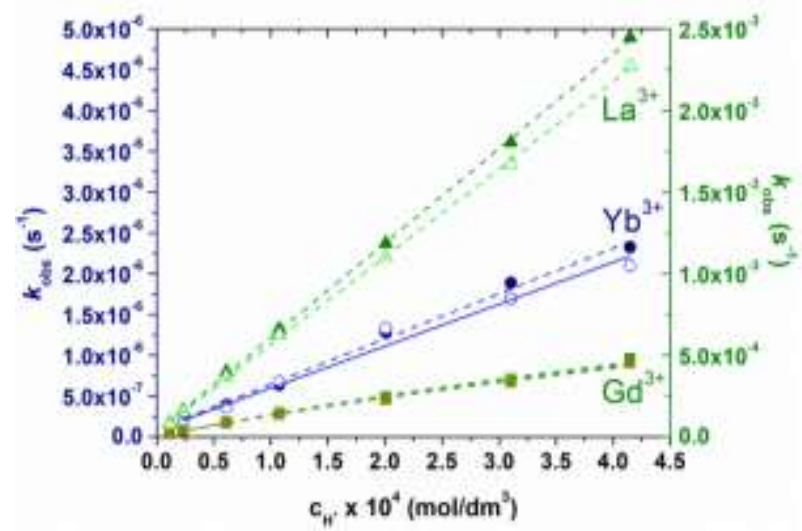

Figure 3. Pseudo-first-order rate constants of dissociation of [Ln(1,4-DO2APA)] complexes $\left(\mathrm{Ln}^{3+}=\mathrm{La}^{3+}\right.$ (triangles, shades of green), $\mathrm{Gd}^{3+}$ (squares, shades of green) or $\mathrm{Yb}^{3+}$ (circles, shades of blue)) as a function of $\mathrm{H}^{+}$ion concentration measured by using a large excess of exchanging $\mathrm{Cu}^{2+}$ ion (for $\mathrm{Gd} \mathrm{c}_{\mathrm{Cu}^{2+}}=3.33$, 5.95, 9.28, and $11.9 \mathrm{mM}$ corresponding to $11.5,20.5,30$ and 41 fold metal excess, respectively; in other $\mathrm{Ln}^{3+}$ systems 11 (3.37 mM, closed symbols) and 31 (10.1 mM, open symbols) fold $\mathrm{Cu}^{2+}$ excess was applied).

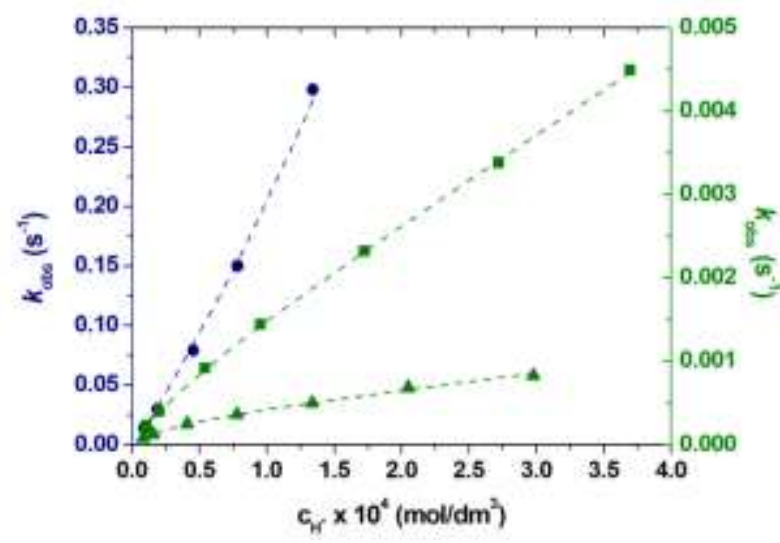

Figure 4. Pseudo-first-order rate constants of dissociation of [Ln(1,7-DO2APA)] complexes $\left(\mathrm{Ln}^{3+}=\mathrm{La}^{3+}\right.$ (green triangles), $\mathrm{Gd}^{3+}$ (green squares) or $\mathrm{Yb}^{3+}$ (blue circles)) as a function of $\mathrm{H}^{+}$ ion concentration measured by using large excess of exchanging $\mathrm{Cu}^{2+}$ ion $\left(\mathrm{c}_{\mathrm{Cu} 2+}=2.02 \mathrm{mM} ; 10.1\right.$ fold metal excess $)$. The lines represent the fits of the data as explained in the text.

The rates of the transmetallation reactions of [Ln(1,4-DO2APA)] complexes were found to be either directly proportional to the $\mathrm{H}^{+}$concentration $\left(\mathrm{Ln}=\mathrm{La}^{3+}\right.$ and $\mathrm{Yb}^{3+}$ ) or showed saturation-like behavior $\left(\mathrm{Gd}^{3+}\right)$. For all systems studied an increase in $\mathrm{Cu}^{2+}$ concentration was found to slow the dissociation (Figure 3, see also Figure S9, Supporting Information). For the $[\mathrm{Ln}(1,7-\mathrm{DO} 2 \mathrm{APA})]$ complexes $\left(\mathrm{Ln}=\mathrm{La}^{3+}\right.$ and $\left.\mathrm{Gd}^{3+}\right)$ saturation-like behavior was observed with hydrogen ion concentration, while the $\mathrm{Yb}^{3+}$ system shows a second order dependence on hydrogen ion concentration (Fig. 4). The pseudo-first-order rate constants characterizing the dissociation of the $\mathrm{Ln}^{3+}$ complexes formed with the 1,7-DO2APA ligand are independent of the $\mathrm{Cu}^{2+}$ ion concentration and thus kinetic experiments were performed while keeping the $\mathrm{Cu}^{2+}$ ion concentration constant (20 fold excess was utilized in all kinetic experiments). The total concentration of the complexes can be expressed by considering the species present in solution under the conditions applied in the kinetic studies. Obviously the majority of the complex is present in its $\mathrm{LnL}$ form, but lowering the $\mathrm{pH}$ may result in the formation of mono- and diprotonated intermediate species (LnHL and $\mathrm{LnH}_{2} \mathrm{~L}$ ), while in the presence of a scavenging metal ion (such as $\mathrm{Cu}^{2+}$ used in the studies), the formation of a dinuclear intermediate $(\mathrm{LnLCu})$ may occur by involving weakly bound (to $\mathrm{Ln}^{3+}$ ions) or uncoordinated donor atom(s) in $\mathrm{Ln}^{3+}$ complexes (the latter complex may even protonate to form a $\mathrm{Ln}(\mathrm{HL}) \mathrm{Cu}$ intermediate). These reaction pathways are summarized in Chart 2.

Chart 2. Dissociation mechanisms of LnL complexes.

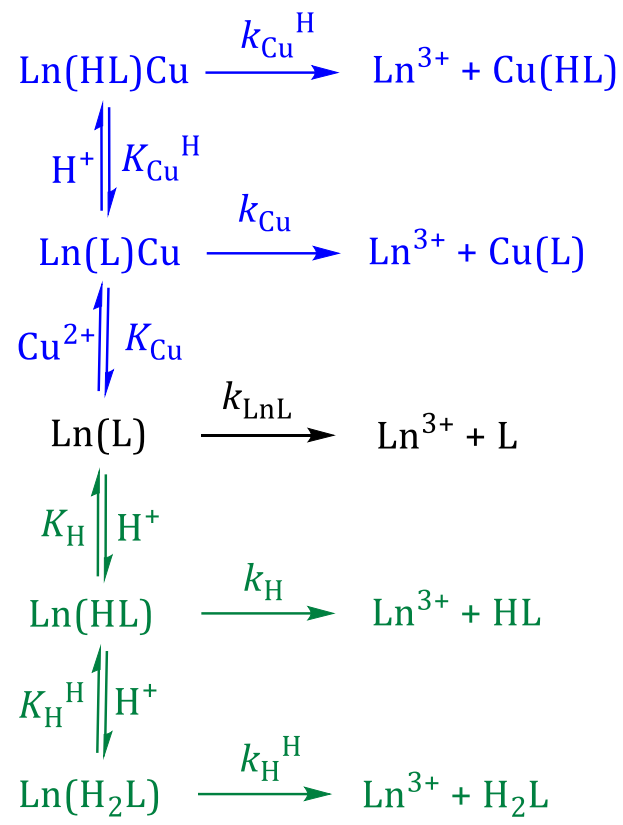

The total concentration of the LnL complexes in kinetic experiments $\left([\mathrm{LnL}]_{\mathrm{tot}}\right)$ can be expressed as the sum of the concentrations of all the different Ln-containing species present in solution:

$$
\begin{aligned}
& {[\operatorname{Ln}(\mathrm{L})]_{\text {tot }}=[\mathrm{LnL}]+[\operatorname{Ln}(\mathrm{HL})]+\left[\operatorname{Ln}\left(\mathrm{H}_{2} \mathrm{~L}\right)\right]+[\operatorname{Ln}(\mathrm{L}) \mathrm{Cu}]+} \\
+ & {[\mathrm{Ln}(\mathrm{HL}) \mathrm{Cu}] \quad(6) }
\end{aligned}
$$

Taking this into account and using eqn (5) the following rate equation is obtained:

$$
-\frac{d[\operatorname{Ln}(\mathrm{L})]_{\mathrm{tot}}}{d t}=k_{\mathrm{d}}[\operatorname{Ln}(\mathrm{L})]_{t o t}=k_{\mathrm{LnL}}[\operatorname{Ln}(\mathrm{L})]+k_{\mathrm{H}}[\operatorname{Ln}(\mathrm{HL})]+
$$

$+k_{\mathrm{H}}^{\mathrm{H}}\left[\operatorname{Ln}\left(\mathrm{H}_{2} \mathrm{~L}\right)\right]+k_{\mathrm{Cu}}[\operatorname{Ln}(\mathrm{L}) \mathrm{Cu}]+k_{\mathrm{Cu}}^{\mathrm{H}}[\operatorname{Ln}(\mathrm{HL}) \mathrm{Cu}]$

The rate constants in eqn (7) characterize the rate of the spontaneous $\left(k_{\mathrm{LnL}}\right)$, proton-assisted $\left(k_{\mathrm{H}}, k_{\mathrm{H}}{ }^{\mathrm{H}}\right)$, copper-assisted $\left(k_{\mathrm{Cu}}\right)$ and proton-copper-assisted $\left(k_{\mathrm{CuH}}\right)$ dissociation pathways. Taking into account the different reaction pathways shown in Chart 2 and the equations determining the $K_{\mathrm{H}}, K_{\mathrm{H}}{ }^{\mathrm{H}}, K_{\mathrm{Cu}}$ and $K_{\mathrm{Cu}}{ }^{\mathrm{H}}$ equilibrium constants, the pseudo-first-order rate constant $\left(k_{\mathrm{d}}\right)$ can be expressed by eqn (8):

$$
k_{\mathrm{d}}=\frac{k_{\mathrm{LnL}}+k_{1}\left[\mathrm{H}^{+}\right]+k_{2}\left[\mathrm{H}^{+}\right]^{2}+k_{3}\left[\mathrm{Cu}^{\mathrm{n}+}\right]+k_{4}\left[\mathrm{Cu}^{2+}\right]\left[\mathrm{H}^{+}\right]}{1+K_{\mathrm{H}}\left[\mathrm{H}^{+}\right]+K_{\mathrm{H}}^{\mathrm{H}}\left[\mathrm{H}^{+}\right]^{2}+K_{\mathrm{Cu}}\left[\mathrm{Cu}^{2+}\right]+K_{\mathrm{Cu}}^{\mathrm{H}}\left[\mathrm{Cu}^{2+}\right]\left[\mathrm{H}^{+}\right]}
$$


where $K_{\mathrm{H}}{ }^{\mathrm{H}}=\left[\mathrm{Ln}\left(\mathrm{H}_{2} \mathrm{~L}\right)\right] /[\mathrm{Ln}(\mathrm{HL})]\left[\mathrm{H}^{+}\right], \quad K_{\mathrm{Cu}}=[\mathrm{Ln}(\mathrm{L}) \mathrm{Cu}] /[\mathrm{Ln}(\mathrm{L})][\mathrm{Cu}]$, $K_{\mathrm{Cu}}{ }^{\mathrm{H}}=[\mathrm{Ln}(\mathrm{HL}) \mathrm{Cu}] /[\mathrm{Ln}(\mathrm{L}) \mathrm{Cu}]\left[\mathrm{H}^{+}\right], \quad k_{1}=k_{\mathrm{H}} \cdot K_{\mathrm{H}}, \quad k_{2}=k_{\mathrm{H}}{ }^{\mathrm{H}} \cdot K_{\mathrm{H}} \cdot K_{\mathrm{H}}{ }^{\mathrm{H}}$, $k_{3}=k_{\mathrm{Cu}} \cdot K_{\mathrm{Cu}}$, and $k_{4}=k_{\mathrm{Cu}}{ }^{\mathrm{H}} K_{\mathrm{Cu}}^{\mathrm{H}}$. Eqn (8) takes into account all the rational/possible dissociation pathways expected to occur under the applied conditions. As for other systems, this expression can be simplified to fit the rate constants determined as a function of $\mathrm{pH}$ (for both systems) and $\mathrm{Cu}^{2+}$ ion concentration (for the complexes of dissociation of 1,4-DO2APA). For instance, the rate of the spontaneous $\left(k_{\mathrm{LnL}}\right)$ dissociation of complexes with macrocyclic ligands derived from DOTA ${ }^{4-}$ is generally extremely low, and therefore its accurate determination is very challenging (for the $[\mathrm{Gd}(\mathrm{DOTA})]^{-}$the values lie in the range of $5 \times 10^{-8}$ to $\left.6.7 \times 10^{-11} \mathrm{~s}^{-1}\right) .{ }^{19,45}$ In the present work, we could obtain reliable data for the rate of spontaneous dissociation only in a few cases (Table 2). For all other systems the given rate constant was fixed to 0 during the data refinement. On the other hand, involvement of the metal ion in the dissociation of 1,7-DO2APA complexes could not be confirmed and thus the terms characterizing this pathway (rate constants $k_{\mathrm{Cu}}$ and $k_{\mathrm{Cu}}{ }^{\mathrm{H}}$ and equilibrium constants $K_{\mathrm{Cu}}$ and $K_{\mathrm{Cu}}{ }^{\mathrm{H}}$ ) were neglected during the data refinement. For the complexes of 1,4-DO2 $\mathrm{APA}^{3-}$ the value of the pseudo-first-order rate constant decreases with increasing $\mathrm{Cu}^{2+}$ concentration, indicating that the dinuclear intermediate formed in the reaction acts as a "dead-end" complex. In agreement with this phenomenon the data fitting returned the stability constants of the dinuclear intermediates $\left(K_{\mathrm{Cu}}\right)$, but the rate constants of the metalassisted dissociation had to be neglected. Altogether, these observations agree with literature data, where the acid assisted dissociation (characterized by $k_{1}$ and $k_{2}$ rate constants) was recognized to be the most important pathway for the dissociation of $\mathrm{Ln}^{3+}$ complexes formed with DOTA ${ }^{4-}$ and its derivatives.
The rate constants obtained by fitting the $k_{\mathrm{d}}$ first-order dissociation rate constants are presented and compared in Table 2. The results show that the complexes of the two regioisomeric ligands behave very differently as far as their dissociation kinetics concerns. The comparison of the $k_{1}$ rate constants shows that removal of an acetate pendant arm from the DO3APA ${ }^{4-}$ ligand results in a considerable drop in the inertness of the complexes formed with $\mathrm{Ln}^{3+}$ ions. ${ }^{24}$ Indeed, the $\mathrm{Gd}^{3+}$ complexes of DO2 $\mathrm{APA}^{3}$ exhibit rate constants 3-4 orders of magnitude higher than that of the $\operatorname{Eu}(\mathrm{DO} 3 \mathrm{APA})$ chelate. This is not unexpected, since a similar increase in the rate constants characterizing the acid-assisted dissociation process can be observed when the data of $\operatorname{Gd}(\mathrm{DOTA})$ and $\mathrm{Gd}(\mathrm{DO} 3 \mathrm{~A})$ are compared. ${ }^{32}$ More striking are the differences observed when the data of the two isomeric complexes are compared. The complexes of the 1,4-regioisomer behave very much like the majority of the complexes formed with DOTA $^{4-}$ and DOTA derivative ligands: the rate constants of acid-assisted dissociation decrease with decreasing size of the $\mathrm{Ln}^{3+}$ ions. However, the complexes of the 1,7-regioisomer become considerably less inert as the size of the $\mathrm{Ln}^{3+}$ ions gets smaller due to the lanthanide contraction. As an interplay between the two opposite trends, the ratios of the $k_{1}$ values of the complexes with the two ligands are 2, 16 and $2.5 \times 10^{5}$ for the $\mathrm{La}^{3+}, \mathrm{Gd}^{3+}$ and $\mathrm{Yb}^{3+}$ complexes, respectively. To the best of our knowledge, the complexes of 1,7-DO2 $\mathrm{APA}^{3-}$ represent the first example of $\mathrm{Ln}^{3+}$ complexes with DOTA derivatives that show an increase in the rate constants of acid-assisted dissociation across the lanthanide series. The different trends observed for the complexes of 1,4-DO2APA and 1,7-DO2APA are very likely related to the labile capping bond effect, which was introduced to explain the differences in terms of water exchange rates of $\mathrm{Gd}^{3+}$ complexes formed with the 1,4- and 1,7-regioisomers investigated here. ${ }^{25}$

Table 2. Dissociation rate and equilibrium constants characterizing the dissociation of the $[\operatorname{Ln}(1,4 \operatorname{DO} 2 \mathrm{APA})]$ and $[\operatorname{Ln}(1,7$ DO2APA)] complexes $\left(\mathrm{I}=0.15 \mathrm{M} \mathrm{NaCl}, 25^{\circ} \mathrm{C}, \mathrm{Ln}=\mathrm{La}, \mathrm{Gd}\right.$ or $\left.\mathrm{Yb}\right)$ and related systems provided for comparison.

\begin{tabular}{|c|c|c|c|c|c|}
\hline Metal (M) / Ligand & & $1,4-\mathrm{DO} 2 \mathrm{APA}^{3-a}$ & 1,7-DO2APA ${ }^{3-a}$ & DO3APA $^{4-b}$ & DOTA $^{4-c}$ \\
\hline & & $0.15 \mathrm{M} \mathrm{NaCl}$ & $0.15 \mathrm{M} \mathrm{NaCl}$ & $0.1 \mathrm{M} \mathrm{KCl}$ & $0.15 \mathrm{M} \mathrm{NaCl}$ \\
\hline \multirow[t]{5}{*}{$\mathrm{La}^{3+}$} & $k_{0}, \mathrm{~s}^{-1}$ & $3.1(7) \times 10^{-5}$ & - & - & - \\
\hline & $k_{1}, \mathrm{M}^{-1} \mathrm{~s}^{-1}$ & $6.02(5)$ & $12.2(7)$ & $2.40 \times 10^{-3}\left(\mathrm{Ce}^{3+}\right)$ & $8.0 \times 10^{-4}\left(\mathrm{Ce}^{3+}\right)$ \\
\hline & $k_{2}, \mathrm{M}^{-2} \mathrm{~s}^{-1}$ & - & $7(2) \times 10^{5}$ & - & $2.0 \times 10^{-3}\left(\mathrm{Ce}^{3+}\right)$ \\
\hline & $K_{\mathrm{H}}$ & - & $3.5(7) \times 10^{4}$ & - & - \\
\hline & $K_{\mathrm{Cu}}$ & $12(1)$ & - & - & - \\
\hline \multirow[t]{8}{*}{$\mathrm{Gd}^{3+}$} & $k_{0}, \mathrm{~s}^{-1}$ & $5.8(6) \times 10^{-6}$ & - & - & $6.7 \times 10^{-11} ;^{d}$ \\
\hline & & & & & $\begin{array}{l}<5 \times 10^{-8} ;{ }^{e} \\
5.8 \times 10^{-10} \\
\left.{ }^{o} \mathrm{C}\right) ;^{f}\end{array}$ \\
\hline & $k_{1}, \mathrm{M}^{-1} \mathrm{~s}^{-1}$ & $1.42(4)$ & $23.5(5)$ & $1.56 \times 10^{-3}\left(\mathrm{Eu}^{3+}\right)$ & $1.8 \times 10^{-6} ;^{d}$ \\
\hline & & & & & $8.4 \times 10^{-6} ;^{e}$ \\
\hline & & & & & $2 \times 10^{-5}\left(37^{\circ} \mathrm{C}\right) ;^{f}$ \\
\hline & $k_{2}, \mathrm{M}^{-2} \mathrm{~s}^{-1}$ & - & $2.1(3) \times 10^{5}$ & $4.8 \times 10^{-4}\left(\mathrm{Eu}^{3+}\right)$ & - \\
\hline & $K_{\mathrm{H}}$ & $7.9(9) \times 10^{2}$ & $2.0(3) \times 10^{4}$ & - & - \\
\hline & $K_{\mathrm{Cu}}$ & $6(2)$ & - & - & - \\
\hline \multirow[t]{5}{*}{$\mathrm{Yb}^{3+}$} & $k_{0}, \mathrm{~s}^{-1}$ & $1.0(5) \times 10^{-7}$ & - & - & - \\
\hline & $k_{1}, \mathrm{M}^{-1} \mathrm{~s}^{-1}$ & $5.8(3) \times 10^{-3}$ & $1.48(7) \times 10^{3}$ & $2.79 \times 10^{-3}$ & - \\
\hline & $k_{2}, \mathrm{M}^{-2} \mathrm{~s}^{-1}$ & - & $6(1) \times 10^{6}$ & - & - \\
\hline & $K_{\mathrm{H}}$ & - & - & - & - \\
\hline & $K_{\mathrm{Cu}}$ & $13(8)$ & - & - & - \\
\hline
\end{tabular}

${ }^{a}$ This work. Values within parenthesis represent the statistical errors of the fits in the last significant digits. ${ }^{b}$ Data from Ref $24 .{ }^{c}$ Data from Ref 46. ${ }^{d}$ Data from Ref 32. ${ }^{e}$ Data from Ref $45 .{ }^{f}$ Data from Ref 43. 
Complexes with regioisomeric ligands derived from a pyclen platform were also found to present significant differences in terms of kinetic inertness. ${ }^{28,29}$ However, the amplitude of the differences in the dissociation rates are considerably less pronounced for the pyclen derivatives. Furthermore, pyclen derivatives present $k_{1}$ values four orders of magnitude lower. This can be rationalized in terms of different rigidity of the parent macrocycles (cyclen vs. pyclen). The pyclen macrocycle is considerably more rigid than cyclen, and thus the energy cost required to rearrange the complex structure during the dissociation process is expected to be higher for the more rigid pyclen derivatives.
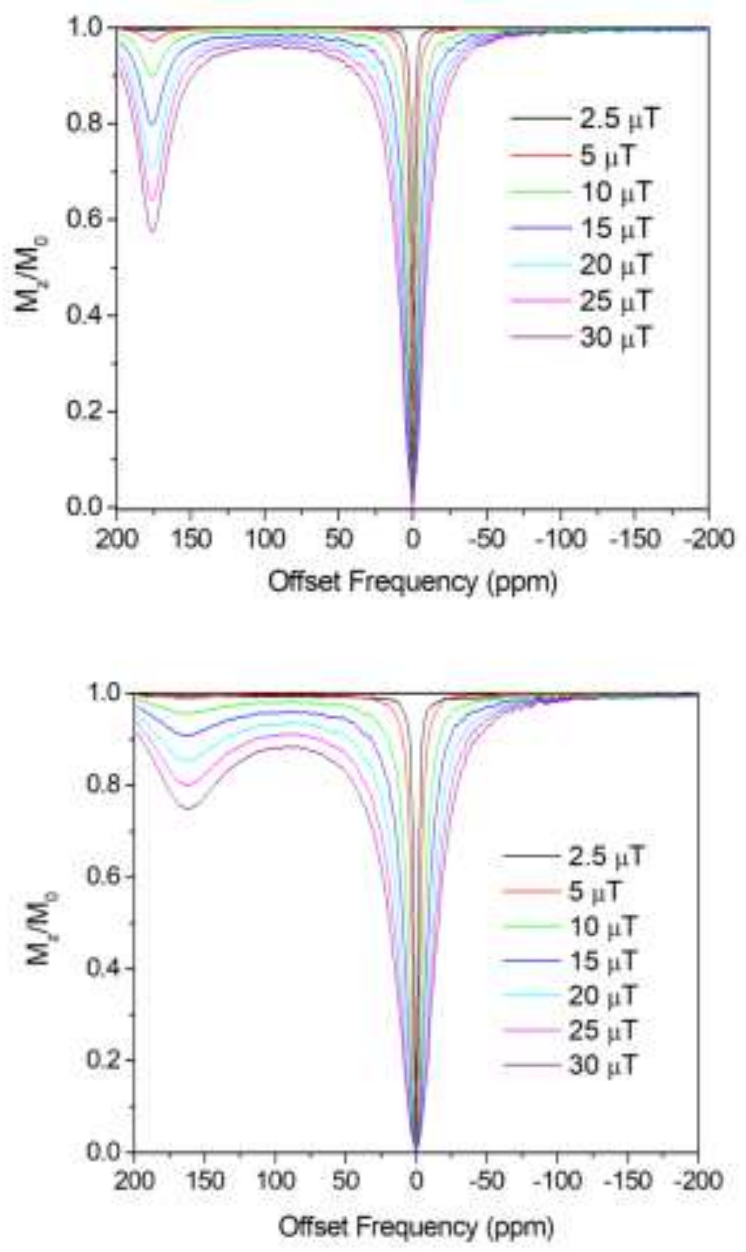

Figure 5. CEST spectra of [ $\mathrm{Yb}(1,7-\mathrm{DO} 2 \mathrm{APA}]$ in $\mathrm{H}_{2} \mathrm{O}(15$ $\mathrm{mM}, \mathrm{pH} 7$, saturation time $10 \mathrm{~s})$ recorded using different saturation powers at 25 (top) and $37^{\circ} \mathrm{C}$ (bottom).

The Z-spectra $\left(25^{\circ} \mathrm{C}\right.$, saturation time $\left.10 \mathrm{~s}\right)$ recorded from a $15 \mathrm{mM}$ solution of [Yb(1,7-DO2APA)] present a prominent CEST feature at $176 \mathrm{ppm}$ that is already visible at low saturation powers $\left(3 \%\right.$ at $\left.B_{1}=5 \mu \mathrm{T}\right)$ and reaches $33 \%$ at $B_{1}=30 \mu \mathrm{T}$ (Fig. 5). The CEST peak becomes broader and shifts to 162 ppm at $37^{\circ} \mathrm{C}\left(29 \%\right.$ at $B_{1}=30 \mu \mathrm{T}$, Fig. S10, Supporting Information). The analysis of the CEST spectra using Bloch equations $^{53}$ provides a $k_{\mathrm{ex}}{ }^{298}$ value of $(15.9 \pm 1.6) \times 10^{3} \mathrm{~s}^{-1}$. This value is similar to that estimated for the $\mathrm{Gd}^{3+}$ analogue using ${ }^{1} \mathrm{H}$ NMRD and ${ }^{17} \mathrm{O}$ NMR measurements $\left(k_{\mathrm{ex}}{ }^{298}=8.8 \times 10^{3}\right.$ $\left.\mathrm{s}^{-1}\right) .{ }^{12}$ Water exchange is faster at $37{ }^{\circ} \mathrm{C}$ with a $k_{\mathrm{ex}}{ }^{310}$ value of $(51.6 \pm 0.9) \times 10^{3} \mathrm{~s}^{-1}$. Thus, CEST experiments confirm the very slow water exchange of the coordinated water molecule in $[\mathrm{Ln}(1,7-\mathrm{DO} 2 \mathrm{APA})]$ complexes, as a result of a strong $\mathrm{Ln}-\mathrm{O}_{\text {water }}$ interaction. Slow water exchange rates were also reported recently for $\left[\mathrm{Ln}(\mathrm{AAZTA})\left(\mathrm{H}_{2} \mathrm{O}\right)\right]^{-}(\mathrm{Ln}=\mathrm{Tm}, \mathrm{Yb})$ derivatives in spite of their negative charge. ${ }^{49,54}$ These results represent another evidence that positively charged $\mathrm{Ln}^{3+}$ complexes (or their derivatives) are not a prerequisite to achieve slow water exchange rates, useful for the design of paraCEST agents.

CEST studies. Chemical exchange saturation transfer experiments allow estimating the exchange rates of protons in slowto-intermediate exchange with bulk water. ${ }^{47-49}$ Among the different $\mathrm{Ln}^{3+}$ ions, $\mathrm{Yb}^{3+}$ induces relatively large pseudocontact shifts without extensive line broadening due to paramagnetic relaxation effects. ${ }^{50-52}$ In a previous work, we showed that the coordinated water molecule present in [Gd(1,7-DO2APA)] shows a very low water exchange rate. ${ }^{25}$ Thus, we performed CEST experiments using the $\mathrm{Yb}^{3+}$ analogue to assess the water exchange rate of the coordinated water molecule and provide further experimental evidence of the labile capping bond phenomenon.

Computational study. The unusual variation of the stability constants and dissociation rate constants across the lanthanide series prompted us to perform a computational study to gain insight into the structural origin of these effects at the molecular level. The structures of the $\left[\mathrm{Ln}(1,4-\mathrm{DO} 2 \mathrm{APA})\left(\mathrm{H}_{2} \mathrm{O}\right)\right] \cdot 2 \mathrm{H}_{2} \mathrm{O}$ and $\left[\mathrm{Ln}(1,7-\mathrm{DO} 2 \mathrm{APA})\left(\mathrm{H}_{2} \mathrm{O}\right)\right] \cdot 2 \mathrm{H}_{2} \mathrm{O}$ systems $(\mathrm{Ln}=\mathrm{La}, \mathrm{Gd}$ or $\mathrm{Yb}$ ) were optimized at the TPSSh/LCRECP/6-31G(d,p) level following the methodology described before ${ }^{55}$ (see also computational details below). The model systems investigated include two second-sphere water molecules, which were found to be crucial to provide a good description of the environment around the coordinated water molecule. ${ }^{56}$ These water molecules are involved in hydrogen-bonding interactions with the inner-sphere water molecule and oxygen atoms of carboxylate groups, but they do not coordinate to the metal ion. Our previous relaxometric and luminescence study pointed to the presence of a hydration equilibrium in [Gd(1,4-DO2APA)] involving a nine-coordinated species with an inner-sphere water molecule and an eight-coordinated species lacking the coordinated water molecule. ${ }^{25}$ We therefore initiated the computational study by exploring the potential energy surface of the $\left[\mathrm{Ln}(1,4-\mathrm{DO} 2 \mathrm{APA})\left(\mathrm{H}_{2} \mathrm{O}\right)\right] \cdot 2 \mathrm{H}_{2} \mathrm{O}$ systems $(\mathrm{Ln}=\mathrm{La}, \mathrm{Gd}$ or $\mathrm{Yb})$ by increasing the distance between the metal ion and the oxygen atom of the coordinated water molecule. The corresponding relaxed potential energy surface scans are shown in Fig. 6. Our results indicate that the hydrated species is clearly more stable for the $\mathrm{La}^{3+}$ complex, while the situation is reversed for $\mathrm{Yb}^{3+}$. In the case of the $\mathrm{Gd}^{3+}$ complex the $q=1$ and $q=0$ species ( $q$ is the number of coordinated water molecules) present very similar energies, which is in nice agreement with 
the hydration number of $q=0.55$ estimated from the analysis of ${ }^{1} \mathrm{H}$ NMRD and ${ }^{17} \mathrm{O}$ NMR data. ${ }^{25}$

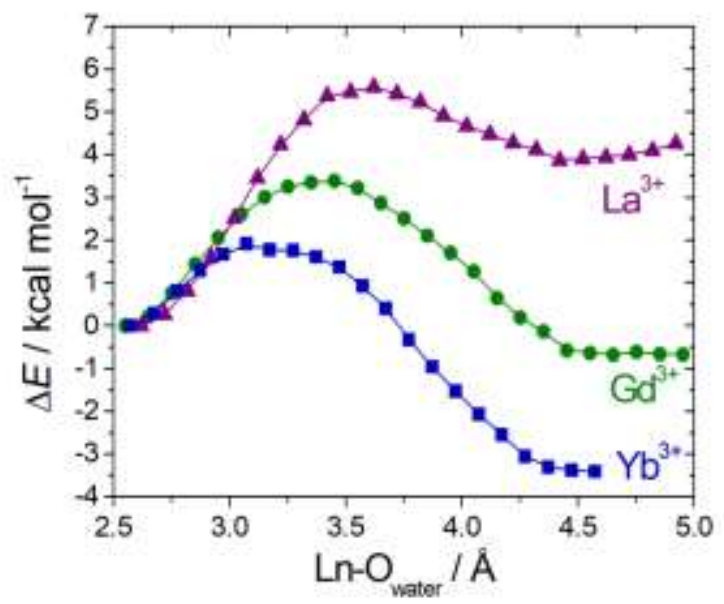

Figure 6. Relaxed potential energy surface scans computed for the $\left[\mathrm{Ln}(1,4-\mathrm{DO} 2 \mathrm{APA})\left(\mathrm{H}_{2} \mathrm{O}\right)\right] \cdot 2 \mathrm{H}_{2} \mathrm{O}$ systems $(\mathrm{Ln}=\mathrm{La}, \mathrm{Gd}$ or $\mathrm{Yb}$ ) by increasing the distance between the lanthanide ion and the oxygen atom of the coordinated water molecule in steps of $0.1 \AA$.

Fig. 7 presents the optimized geometries of the $\left[\mathrm{Yb}(1,7-\mathrm{DO} 2 \mathrm{APA})\left(\mathrm{H}_{2} \mathrm{O}\right)\right] \cdot 2 \mathrm{H}_{2} \mathrm{O}$ and $\left[\mathrm{Yb}(1,4-\mathrm{DO} 2 \mathrm{APA})\left(\mathrm{H}_{2} \mathrm{O}\right)\right] \cdot 2 \mathrm{H}_{2} \mathrm{O}$ complexes and the numbering scheme adopted for the donor atoms of the ligands. The $\left[\mathrm{Yb}(1,7-\mathrm{DO} 2 \mathrm{APA})\left(\mathrm{H}_{2} \mathrm{O}\right)\right] \cdot 2 \mathrm{H}_{2} \mathrm{O}$ complex presents a capped square antiprismatic coordination geometry in which an oxygen atom of the picolinate group (O3) occupies the capping position. The steric compression around the capping position results in a rather long Yb-O3 distance (2.385 $\AA$ ) compared to the distances involving the oxygen atoms of acetate groups ( $\mathrm{Yb}-\mathrm{O} 1=2.278 \AA$; Yb-O2 = $2.320 \AA$ ). This is in line with the capping bond effect introduced recently by our group..$^{25,28,29}$ In $\left[\mathrm{Yb}(1,4-\mathrm{DO} 2 \mathrm{APA})\left(\mathrm{H}_{2} \mathrm{O}\right)\right] \cdot 2 \mathrm{H}_{2} \mathrm{O}$, the capping position is occupied by the coordinated water molecule, which presents a very long $\mathrm{Yb}-\mathrm{O} 1 \mathrm{w}$ distance $(2.483 \AA$ ) compared to that obtained for the 1,7-DO2APA derivative (2.390 $⿱$ ) $)$. As a result, the most stable for of the $\mathrm{Yb}^{3+}$ complex with 1,4-DO2APA does not contain a coordinated water molecule. Thus, the change in hydration state on going from the $\mathrm{La}^{3+}$ complex $(q=1)$ to $\mathrm{Yb}^{3+}(q=0)$ is a direct consequence of the steric compression around the capping water binding site. In $\left[\mathrm{Ln}(1,7-\mathrm{DO} 2 \mathrm{APA})\left(\mathrm{H}_{2} \mathrm{O}\right)\right] \cdot 2 \mathrm{H}_{2} \mathrm{O}$ complexes the coordinated water molecule occupies a coordination position in the upper square plane of the SAP coordination polyhedron, and thus remains tightly bound throughout the lanthanide series from $\mathrm{La}^{3+}$ to $\mathrm{Yb}^{3+}$.

The bond distances of the metal coordination environment in lanthanide complexes generally decrease across the lanthanide series due to the lanthanide contraction. ${ }^{57}$ As a consequence, an analysis of the strength of the Ln-donor bonds in terms of bond distances is not straightforward. Thus, we calculated the electron densities at the critical points of the Ln-donor bonds $\left(\rho_{\mathrm{BCP}}\right)$, which have been shown to provide a measure of the strength of the concerned bonds. ${ }^{26,27}$ The results of this analysis are presented in Fig. 8 (see also Table S1, Supporting Information). The $\mathrm{Ln}-\mathrm{O}$ bonds involving carboxylate groups present higher $\rho_{\mathrm{BCP}}$ values than the Ln-N bonds, as would be expected considering the hard nature of the $\mathrm{Ln}^{3+}$ ions in Pearson's classification. All Ln-donor bonds are characterised by positive values of the Laplacian of the electron density at the bond critical points $\left(\nabla^{2} \rho_{\mathrm{BCP}}\right.$, Table $\mathrm{S} 1$, Supporting Information) and $\rho_{\mathrm{BC}}$ values well below $0.2 \mathrm{au}$. This indicates that the electron density is locally depleted at the bond critical points, pointing to ionic interactions. ${ }^{58,59}$ The electron densities of the critical points at the $\mathrm{Ln}-\mathrm{O}_{\text {water }}$ bonds are higher for the complexes of 1,7-DO2 $\mathrm{APA}^{3-}$, which is in agreement with the slow water exchange rate measured for the $\mathrm{Gd}^{3+}$ complex. ${ }^{26,27}$

For the $\left[\mathrm{Ln}(1,7-\mathrm{DO} 2 \mathrm{APA})\left(\mathrm{H}_{2} \mathrm{O}\right)\right] \cdot 2 \mathrm{H}_{2} \mathrm{O}$ complexes, the $\rho_{\mathrm{BCP}}$ characterizing the donor atoms delineating the upper plane of the square antiprism $(\mathrm{O} 1, \mathrm{O} 2$ and $\mathrm{O} 1 \mathrm{w})$ increase across the lanthanide series, which indicates that the concerned bonds become stronger as a result of the increased positive charge density of the metal ion. However, the Ln-O3 bond, which involves the oxygen atom of the picolinate group, weakens across the lanthanide series due to an increasing compression around the capping bond. Thus, the weaker interaction of the metal ion with the picolinate oxygen atom appears to be responsible for the decrease in complex stability for the smaller $\mathrm{Ln}^{3+}$ ions. The same effect is likely responsible for the increasing acid-catalyzed dissociation rates observed across the $4 \mathrm{f}$ period. The acid-catalyzed dissociation of the complex proceeds through the formation of a protonated species involving negatively charged carboxylate groups of the ligands. Once protonated, a cascade of proton transfer events causes the protonation of the more basic amine nitrogen atoms, provoking complex dissociation. The relatively weak coordination of the picolinate group likely facilitates its decoordination upon protonation, so that the proton can be more easily transferred to the amine nitrogen atoms.

The trends obtained for the $\rho_{\mathrm{BCP}}$ values in the complexes of 1,4-DO2 $\mathrm{APA}^{3-}$ indicate that all $\mathrm{Ln}-\mathrm{O}$ bonds involving the carboxylate groups of the ligand become stronger across the lanthanide series, explaining the increasing stability of the complexes as well as the increasing kinetic inertness with respect to complex dissociation. The astonishing increase of the kinetic inertness on going from $\mathrm{Gd}^{3+}$ to $\mathrm{Yb}^{3+}$ is the result of the more compact structure of the complex associated to the reduced coordination number in the $q=0 \mathrm{Yb}^{3+}$ complex. The coordinated water molecule in the complexes with 1,7-DO2APA becomes more tightly bound across the series, while the reverse situation is observed for the analogues of 1,4-DO2APA. 

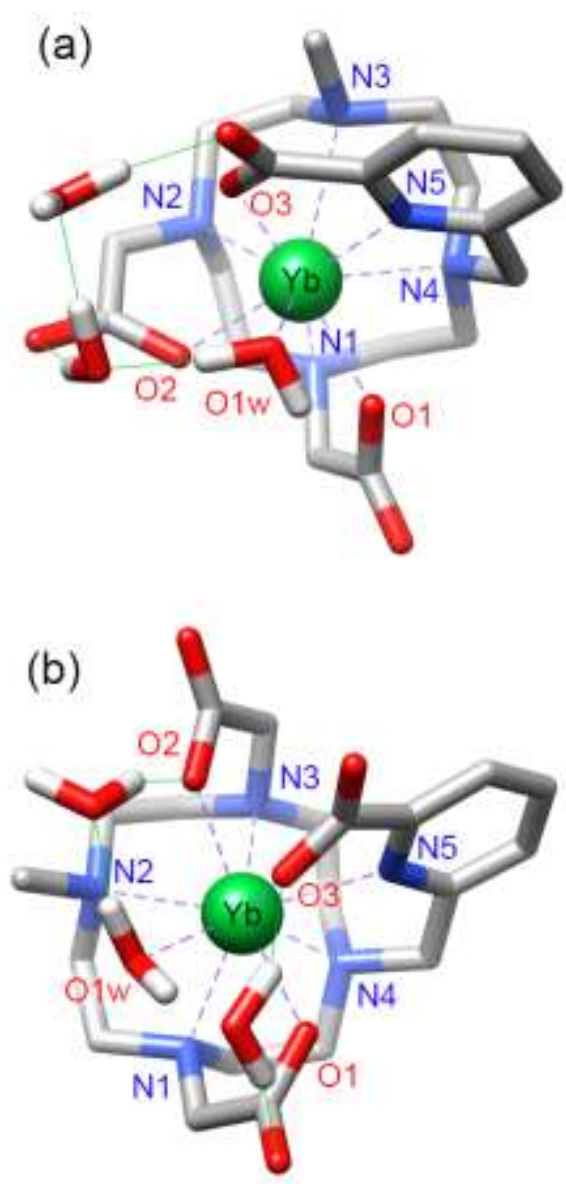

Figure 7. Optimized geometries of the $\left[\mathrm{Yb}(1,4-\mathrm{DO} 2 \mathrm{APA})\left(\mathrm{H}_{2} \mathrm{O}\right)\right] \cdot 2 \mathrm{H}_{2} \mathrm{O} \quad$ (a) and $\left[\mathrm{Yb}(1,7-\mathrm{DO} 2 \mathrm{APA})\left(\mathrm{H}_{2} \mathrm{O}\right)\right] \cdot 2 \mathrm{H}_{2} \mathrm{O}$ (b) systems obtained with DFT calculations.

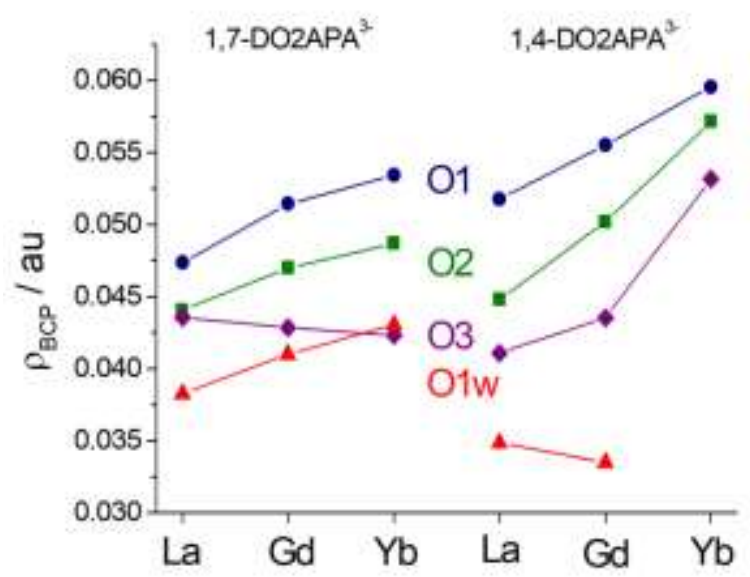

Figure 8. Electron densities at the bond critical points $\left(\rho_{\mathrm{BCP}}\right)$ involving $\mathrm{Ln}-\mathrm{O}$ bonds in $\left[\mathrm{Ln}(1,4-\mathrm{DO} 2 \mathrm{APA})\left(\mathrm{H}_{2} \mathrm{O}\right)\right] \cdot 2 \mathrm{H}_{2} \mathrm{O}(\mathrm{Ln}$ $=\mathrm{La}, \mathrm{Gd}), \quad[\mathrm{Yb}(1,4-\mathrm{DO} 2 \mathrm{APA})] \quad$ and $\left[\mathrm{Ln}(1,7-\mathrm{DO} 2 \mathrm{APA})\left(\mathrm{H}_{2} \mathrm{O}\right)\right] \cdot 2 \mathrm{H}_{2} \mathrm{O} \quad(\mathrm{Ln}=\mathrm{La}, \quad \mathrm{Gd}, \quad \mathrm{Yb})$ complexes.

\section{CONCLUSIONS}

We have presented a detailed analysis of the thermodynamic stability and dissociation kinetics of lanthanide complexes with two cyclen-based regioisomeric ligands. The two series of complexes present different stability trends across the lanthanide series: The complexes of 1,4-DO2APA show the typical increase in stability across the series, while the stability of the 1,7-DO2APA analogues decreases on going from $\mathrm{Gd}^{3+}$ to $\mathrm{Lu}^{3+}$. The rates of dissociation of 1,4-DO2APA complexes decrease slightly from $\mathrm{La}^{3+}$ to $\mathrm{Gd}^{3+}$ and then drop dramatically for the $\mathrm{Yb}^{3+}$ complex, an effect that is related to a more tight coordination of the ligand, associated to the higher positive charge density of the metal ion and a reduced coordination number.

The rates of dissociation of the complexes with 1,7DO2APA show an unprecedented increase on moving to the right along the lanthanide series. DFT studies show that this is likely related to the coordination of the picolinate oxygen atom at the sterically demanding apical position. The coordination of the picolinate group becomes weaker on decreasing the ionic radius of the $\mathrm{Ln}^{3+}$ ion, facilitating the decoordination of this group upon protonation. The coordination of the picolinate oxygen atom at the apical position leaves the water molecule tightly coordinated at the upper square plane of the square antiprismatic coordination polyhedron. As a result, the coordinated water molecule exhibits a low exchange rate with bulk water, as demonstrated by CEST experiments for the $\mathrm{Yb}^{3+}$ complex. While the low kinetic inertness of this complex precludes any potential application as MRI contrast agent, this result shows that the slow water exchange rates required for CEST agents may be attained placing water molecules at noncapping positions.

In summary, the arrangement of the donor atoms of the ligand around the $\mathrm{Ln}^{3+}$ ion plays a crucial role in the thermodynamic and kinetic properties of the complexes. We have shown that dissociation rates may vary up to three orders of magnitude across the lanthanide series. This unprecedented observation shows that the kinetic inertness of a complex may not be assured when one lanthanide ion is changed by another. Furthermore, the rates of dissociation of lanthanide complexes may vary by up to six orders of magnitude by changing the arrangement of the donor atoms around the metal ion. These issues must be carefully considered in ligand design in addition to the number and type of donor atoms.

\section{EXPERIMENTAL AND COMPUTATIONAL SECTION}

Equilibrium Measurements. The metal salts and other materials used in equilibrium experiments were of the highest analytical grade. Standardized $\mathrm{Na}_{2} \mathrm{H}_{2}$ EDTA was used to determine the concentration of the $\mathrm{MgCl}_{2}, \mathrm{CaCl}_{2}, \mathrm{CuCl}_{2}$, $\mathrm{ZnCl}_{2}$ and $\mathrm{LnCl}_{3}$ solutions by complexometric titration in the presence of eriochrome black $\mathrm{T}\left(\mathrm{MgCl}_{2}\right)$, Patton \& Reeder $\left(\mathrm{CaCl}_{2}\right)$, murexid $\left(\mathrm{CuCl}_{2},\right)$ and xylenol orange $\left(\mathrm{ZnCl}_{2}\right.$ and $\mathrm{LnCl}_{3}$ ) as the indicators. 
The concentration of the ligands was determined by $\mathrm{pH}-$ potentiometric titration in the presence and absence of a large excess of $\mathrm{CaCl}_{2}$. To obtain the protonation constants of 1,4-DO2 $\mathrm{APA}^{3-}$ and 1,7-DO2 $\mathrm{APA}^{3-}$ acidified $(\mathrm{HCl})$ ligand solutions $(2 \mathrm{mM})$ were titrated with $0.15 \mathrm{M} \mathrm{NaOH}$ in the presence of $0.15 \mathrm{M} \mathrm{NaCl}$ as ionic strength. The stability and protonation constants of the $\mathrm{Mg}^{2+}, \mathrm{Ca}^{2+}, \mathrm{Cu}^{2+}$ (by using $1.0 \mathrm{M}$ ionic background for this particular system) and $\mathrm{Zn}^{2+}$ complexes were determined by $\mathrm{pH}$ potentiometric titration where the metal to ligand ratios were $1: 1$ using $1.7 \mathrm{mM}$ ligand concentration (100-200 V(mL) $\mathrm{NaOH}-\mathrm{pH}$ data pairs were recorded). The $\mathrm{pH}$-potentiometric titrations were carried out with a Metrohm 888 Titrando workstation with the use of a Metrohm 6.0234.100 combined electrode in the $\mathrm{pH}$ range of 1.70-11.80. For the calibration of the $\mathrm{pH}$ meter, KH-phtalate $(\mathrm{pH}=4.005)$ and borax $(\mathrm{pH}=9.177)$ buffers were used. The titrated samples $(6 \mathrm{~mL})$ were thermostated at $25^{\circ} \mathrm{C}$ and mechanically stirred under inert atmosphere $\left(\mathrm{N}_{2}\right)$. The method proposed by Irving et al. ${ }^{60}$ was used to calculate the $\mathrm{H}^{+}$concentrations from the measured $\mathrm{pH}$ values. The Irving factor and the ion product of water $\left(\mathrm{p} K_{\mathrm{w}}=13.75\right)$ was determined in the same $\mathrm{HCl}-\mathrm{NaOH}$ titration experiment. In the case of the $\mathrm{Cu}^{2+}$ complexes pH-potentiometry was supported by spectrophotometric measurements performed on batch samples, since the formation of protonated $\mathrm{Cu}^{2+}$ complexes was found to be quantitative even near $\mathrm{pH}=1.5$ (thus only the deprotonation events of the complexes could be characterized in the $\mathrm{pH}$ range of 1.70-11.80). The absorbance spectra were recorded with a Cary 100 Bio spectrophotometer at $25^{\circ} \mathrm{C}$, using $1.0 \mathrm{~cm}$ cells. For determining the stability constants of the $\mathrm{Cu}^{2+}$ complexes 8 separated samples were prepared with different acid concentrations (in the acid concentration range of $0.01-0.70$ $\mathrm{M})$ and the absorbance data measured at 7 wavelengths in the $650-800 \mathrm{~nm}$ range were used for the calculations. In these experiments, the ionic strength of the samples was set to $1.0 \mathrm{M}$ $(\mathrm{cHCl}+\mathrm{cNaCl}=1.0 \mathrm{M})$, and thus the protonation constants of the ligands were also determined under the same conditions (Table 1). Beside the $\mathrm{pH}$-potentiometric data, the measured absorbance and molar absorptivity data determined independently were taken into account to determine the equilibrium constants.

Due to the relatively slow formation of the $\mathrm{Ln}^{3+}$ complexes, the so called "out-of-cell" technique was utilized to determine their stability constants. Samples with total volume of $2.50 \mathrm{~mL}$ containing the $\mathrm{Ln}^{3+}$ ion $(2 \mathrm{mM})$ and the ligand $(2 \mathrm{mM})$ were prepared in the $\mathrm{pH}$ range of about $3.0-6.5$. The ionic strength in the samples was set to $0.15 \mathrm{M}$ by using $\mathrm{NaCl}$. The closed samples were kept at $25{ }^{\circ} \mathrm{C}$ for 4 weeks to reach the equilibri$\mathrm{um}$ and then their $\mathrm{pH}$ and relaxivity (for the $\mathrm{Gd}^{3+}$ complexes) were measured. These data allowed determining the stability constants by using the $\mathrm{pH}$-potentiometric (by knowing the acid concentration of the samples and their $\mathrm{pH}$ at equilibrium) and ${ }^{1} \mathrm{H}$ relaxometric method (by using the $\mathrm{pH}$ and the relaxivities of the samples). These two sets of data were fitted simultaneously.

The equilibrium constants have been calculated from the ti- tration data with the program PSEQUAD. ${ }^{6}$

Kinetic studies. The rates of the dissociation of the $\mathrm{Ln}^{3+}$ complexes in metal exchange reactions taking place with the $\mathrm{Cu}^{2+}$ ion were studied by spectrophotometry at $300 \mathrm{~nm}$ in thermostated cells $\left(1.0 \mathrm{~cm}, 25{ }^{\circ} \mathrm{C}\right)$ with Cary 100 Bio $\left(1,4-\mathrm{DO} 2 \mathrm{APA}^{3-}\right)$ and Jasco V770 (1,7-DO2APA $\left.{ }^{3-}\right)$ spectrophotometers in the presence of $0.15 \mathrm{M} \mathrm{NaCl}$. The concentration of the $[\mathrm{Ln}(1,4-\mathrm{DO} 2 \mathrm{APA})]$ and $[\mathrm{Ln}(1,7-\mathrm{DO} 2 \mathrm{APA})] \mathrm{com}-$ plexes was $0.3 \mathrm{mM}$ and $0.2 \mathrm{mM}$, respectively. The $\mathrm{Cu}^{2+}$ ion was used in 10- to 40-fold excess for the [ $\operatorname{Ln}(1,4-\mathrm{DO} 2 \mathrm{APA})]$ complexes, while a 10-fold excess was applied in the case of [Ln(1,7-DO2APA)] complexes. A non-coordinating buffer at $0.05 \mathrm{M}$ concentration was used to keep the $\mathrm{pH}$ constant (DMP: 1,4-dimethylpiperazine, $\mathrm{p} K_{\mathrm{a}}=4.17$ ). The exchange reactions were studied in the $\mathrm{pH}$ range 3.4-5.0. For the calculation of the pseudo-first-order rate constants $\left(k_{\mathrm{d}}\right)$, the absorbance values measured at different $t$ times were fitted to the following equation:

$A_{t}=\left(A_{0}-A_{e}\right) e^{-k_{d} t}+A_{e}$

where $A_{0}, A_{\mathrm{t}}$ and $A_{\mathrm{e}}$ are the absorbance values measured at the start, at time $t$ and at equilibrium, respectively.

Relaxometric measurements. Measurements of longitudinal relaxation times $\left(T_{1}\right)$ were performed by using a Bruker Minispec MQ-20 NMR Analyzer operating at $0.49 \mathrm{~T}$ (corresponding to $20 \mathrm{MHz}$ proton Larmor frequency) at $25.0 \pm 0.2{ }^{\circ} \mathrm{C}$ (set by a circulating water bath). The $T_{1}$ values were determined with the inversion recovery method $\left(180^{\circ}-\tau-90^{\circ}\right)$ by averaging 4-6 data points obtained at 10 different $\tau$ delay values.

NMR studies. CEST spectra have been recorded at 25 and $37{ }^{\circ} \mathrm{C}$, at diverse radiofrequency fields $\left(\mathrm{B}_{1}=2.5,5,10,15,20\right.$, 25 and $30 \mu \mathrm{T}$ ) on a Bruker Advance $300 \mathrm{MHz}$ spectrometer. Z-spectra of $15 \mathrm{mM}$ complex aqueous solutions were performed using a saturation time of $10 \mathrm{~s}$ and a $2 \mathrm{ppm}$ frequency resolution. The $\mathrm{pH}$ of the solution was adjusted to $\mathrm{pH} 7.0$ by adding 0.01 to $0.1 \mathrm{M} \mathrm{NaOH}$ or $\mathrm{HCl}$ solutions. The exact concentration of the solutions was determined by elemental analysis of the complexes.

DFT calculations. Full geometry optimizations of the $\left[\mathrm{Ln}(1,4-\mathrm{DO} 2 \mathrm{APA})\left(\mathrm{H}_{2} \mathrm{O}\right)\right] \cdot 2 \mathrm{H}_{2} \mathrm{O}$,

$\left[\mathrm{Ln}(1,7-\mathrm{DO} 2 \mathrm{APA})\left(\mathrm{H}_{2} \mathrm{O}\right)\right] \cdot 2 \mathrm{H}_{2} \mathrm{O}(\mathrm{Ln}=\mathrm{La}, \mathrm{Gd}$ or $\mathrm{Yb})$ and [Yb(1,4-DO2APA)] systems were performed employing DFT calculations at the TPSSh/LCRECP/6-31G(d,p $)^{62}$ level with the Gaussian 09 package (Revision E.01) ${ }^{63}$ LCRECP refers to the large-core quasi-relativistic pseudopotential of Dolg el al. and its associated $(7 \mathrm{~s} 6 \mathrm{p} 5 \mathrm{~d}) /[5 \mathrm{~s} 4 \mathrm{p} 3 \mathrm{~d}]-\mathrm{GTO}$ valence basis set. ${ }^{64}$ Solvent effects were included by using the polarizable continuum model (PCM), in particular the integral equation formalism (IEFPCM) variant. ${ }^{65}$ No symmetry constraints have been imposed during the optimizations. An ultrafine integration grid and the default SCF energy convergence threshold $\left(10^{-8}\right.$ a. u.) were used. The stationary points found on the potential energy surfaces as a result of geometry optimizations were characterized via frequency analysis. The electron density $(\rho)$ and its Laplacian $\left(\nabla^{2} \rho\right)$ at the bond critical points (BCPs) were computed with the Multiwnf program (version 3.2). ${ }^{66}$ 


\section{ASSOCIATED CONTENT}

Supporting Information

The Supporting Information is available free of charge on the ACS Publications website at DOI: XXXXX.

Additional kinetic data, speciation diagrams, CEST spectra and DFT data (PDF).

\section{AUTHOR INFORMATION}

Corresponding Authors

*E-mail: gyula.tircso@ science.unideb.hu (G. T.)

*E-mail: aurora.rodriguez@udc.es (A. R.-R.)

ORCID

Aurora Rodríguez-Rodríguez: 0000-0002-4951-4470

Rosa Pujales-Paradela: 0000-0002-9540-3966

Goran Angelovski: 0000-0002-8883-2631

Éva Tóth: 0000-0002-3200-6752

David Esteban-Gómez: 0000-0001-6270-1660

Raphaël Tripier: 0000-0001-9364-788X

Carlos Platas-Iglesias: 0000-0002-6989-9654

Gyula Tircsó: 0000-0002-7896-7890

Author Contributions

The manuscript was written through contributions of all authors. All authors have given approval to the final version of the manuscript.

Notes

The authors declare no competing financial interest.

\section{ACKNOWLEDGMENT}

The research was funded by the GINOP-2.3.2-15-201600008 project supported by the EU and co-supported by the European Regional Development Fund, by the Hungarian National Research, Development and Innovation Office (NKFIH K-120224 and 128201 projects), the bilateral Hungarian-Spanish science and technology cooperation program (2019-2.1.11-TÉT-2019-00084) and the COST Action CA15209 European Network on NMR Relaxometry. Authors C. P.-I., D. E.-G. and A. R.-R. also thank Ministerio de Economía y Competitivad (CTQ2016-76756-P) for generous financial support and Centro de Supercomputación de Galicia (CESGA) for providing the computer facilities.

\section{REFERENCES}

(1) Stasiuk, G. J.; Long, N. J. The Ubiquitous DOTA and Its Derivatives: The Impact of 1,4,7,10Tetraazacyclododecane-1,4,7,10-Tetraacetic Acid on Biomedical Imaging. Chem. Commun. 2013, 49, 27322746.

(2) Wahsner, J.; Gale, E. M.; Rodríguez-Rodríguez, A.; Caravan, P. Chemistry of MRI Contrast Agents: Current Challenges and New Frontiers. Chem. Rev. 2019, 119, 957-1057.

(3) The Chemistry of Contrast Agents in Medical Magnetic Resonance Imaging, 2nd Edition, 2nd Edn.; Merbach, A. E., Helm, L., Tóth, É., Eds.; WILEY: New York, 2013.
Evbuomwan, O. M.; Terreno, E.; Aime, S.; Sherry, A. D. CEST and PARACEST Agents for Molecular Imaging. The Chemistry of Molecular Imaging. October 31, 2014, pp 225-243.

(5) Viswanathan, S.; Kovacs, Z.; Green, K. N.; Ratnakar, S. J.; Sherry, A. D. Alternatives to Gadolinium-Based Metal Chelates for Magnetic Resonance Imaging. Chem. Rev. 2010, 110, 2960-3018.

Woods, M.; Woessner, D. E.; Sherry, A. D. Paramagnetic Lanthanide Complexes as PARACEST Agents for Medical Imaging. Chem. Soc. Rev. 2006, 35, 500-511.

Chalmers, K. H.; Kenwright, A. M.; Parker, D.; Blamire, A. M. ${ }^{19}$ F-Lanthanide Complexes with Increased Sensitivity for ${ }^{19} \mathrm{~F}$-MRI: Optimization of the MR Acquisition. Magn. Reson. Med. 2011, 66, 931-936.

Placidi, M. P.; Botta, M.; Kálmán, F. K.; Hagberg, G. E.; Baranyai, Z.; Krenzer, A.; Rogerson, A. K.; Tóth, I.; Logothetis, N. K.; Angelovski, G. Aryl-Phosphonate Lanthanide Complexes and Their Fluorinated Derivatives: Investigation of Their Unusual Relaxometric Behavior and Potential Application as Dual Frequency ${ }^{1} \mathrm{H} /{ }^{19}$ F MRI Probes. Chem. - A Eur. J. 2013, 19, 11644 11660 .

Kadjane, P.; Platas-Iglesias, C.; Boehm-Sturm, P.; Truffault, V.; Hagberg, G. E.; Hoehn, M.; Logothetis, N. K.; Angelovski, G. Dual-Frequency Calcium-Responsive MRI Agents. Chem. - A Eur. J. 2014, 20, 7351-7362.

(10) Harvey, P.; Blamire, A. M.; Wilson, J. I.; Finney, K.-L. N. A.; Funk, A. M.; Senanayake, P. K.; Parker, D. Moving the Goal Posts: Enhancing the Sensitivity of PARASHIFT Proton Magnetic Resonance Imaging and Spectroscopy. Chem. Sci. 2013, 4, 4251-4258.

(11) Mason, K.; Rogers, N. J.; Suturina, E. A.; Kuprov, I.; Aguilar, J. A.; Batsanov, A. S.; Yufit, D. S.; Parker, D. PARASHIFT Probes: Solution NMR and X-Ray Structural Studies of Macrocyclic Ytterbium and Yttrium Complexes. Inorg. Chem. 2017, 56, 4028-4038.

(12) Eliseeva, S. V.; Bünzli, J.-C. G. Lanthanide Luminescence for Functional Materials and BioSciences. Chem. Soc. Rev. 2010, 39, 189-227.

Bünzli, J.-C. G. Lanthanide Luminescence for Biomedical Analyses and Imaging. Chem. Rev. 2010, 110, 2729-2755.

(14) Delbianco, M.; Sadovnikova, V.; Bourrier, E.; Mathis, G.; Lamarque, L.; Zwier, J. M.; Parker, D. Bright, Highly Water-Soluble Triazacyclononane Europium Complexes to Detect Ligand Binding with Time-Resolved FRET Microscopy. Angew. Chem. Int. Ed. 2014, 53, 1071810722 .

(15) Starck, M.; Pal, R.; Parker, D. Structural Control of Cell Permeability with Highly Emissive Europium(III) Complexes Permits Different Microscopy Applications. Chem. - A Eur. J. 2016, 22, 570-580. 
Grobner, T. Gadolinium - A Specific Trigger for the Development of Nephrogenic Fibrosing Dermopathy and Nephrogenic Systemic Fibrosis? Nephrol. Dial. Transplant. 2006, 21, 1104-1108.

(17) Layne, K. A.; Dargan, P. I.; Archer, J. R. H.; Wood, D. M. Gadolinium Deposition and the Potential for Toxicological Sequelae - A Literature Review of Issues Surrounding Gadolinium-Based Contrast Agents. Br. J. Clin. Pharmacol. 2018, 84, 2522-2534.

(18) Baranyai, Z.; Brücher, E.; Uggeri, F.; Maiocchi, A.; Tóth, I.; Andrási, M.; Gáspár, A.; Zékány, L.; Aime, S. The Role of Equilibrium and Kinetic Properties in the Dissociation of Gd[DTPA-Bis(Methylamide)] (Omniscan) at near to Physiological Conditions. Chem. A Eur. J. 2015, 21, 4789-4799.

(19) Baranyai, Z.; Pálinkás, Z.; Uggeri, F.; Maiocchi, A.; Aime, S.; Brücher, E. Dissociation Kinetics of OpenChain and Macrocyclic Gadolinium(III)Aminopolycarboxylate Complexes Related to Magnetic Resonance Imaging: Catalytic Effect of Endogenous Ligands. Chem. - A Eur. J. 2012, 18, 16426-16435.

(20) Pasha, A.; Tircsó, G.; Benyó, E. T.; Brücher, E.; Sherry, A. D. Synthesis and Characterization of DOTA-(Amide) 4 Derivatives: Equilibrium and Kinetic Behavior of Their Lanthanide(III) Complexes. Eur. J. Inorg. Chem. 2007, 4340-4349.

(21) Funk, A. M.; Clavijo Jordan, V.; Sherry, A. D.; Ratnakar, S. J.; Kovacs, Z. Oxidative Conversion of a Europium(II)-Based $\mathrm{T}_{1}$ Agent into a Europium(III)Based ParaCEST Agent That Can Be Detected in Vivo by Magnetic Resonance Imaging. Angew. Chem. Int. Ed. 2016, 55, 5024-5027.

(22) Ratnakar, S. J.; Soesbe, T. C.; Lumata, L. L.; Do, Q. N.; Viswanathan, S.; Lin, C. Y.; Sherry, A. D.; Kovacs, Z. Modulation of CEST Images in Vivo by $T_{1}$ Relaxation: A New Approach in the Design of Responsive PARACEST Agents. J. Am. Chem. Soc. 2013, 135, 14904-14907.

(23) Fernando, W. S.; Martins, A. F.; Zhao, P.; Wu, Y.; Kiefer, G. E.; Platas-Iglesias, C.; Sherry, A. D. Breaking the Barrier to Slow Water Exchange Rates for Optimal Magnetic Resonance Detection of ParaCEST Agents. Inorg. Chem. 2016, 55, 3007-3014.

(24) Regueiro-Figueroa, M.; Bensenane, B.; Ruscsák, E.; Esteban-Gómez, D.; Charbonnière, L. J.; Tircsó, G.; Tóth, I.; De Blas, A.; Rodríguez-Blas, T.; Platas-Iglesias, C. Lanthanide Dota-like Complexes Containing a Picolinate Pendant: Structural Entry for the Design of $\mathrm{Ln}^{\mathrm{III}}$-Based Luminescent Probes. Inorg. Chem. 2011, 50, 4125-4141.

(25) Rodríguez-Rodríguez, A.; Regueiro-Figueroa, M.; Esteban-Gómez, D.; Rodríguez-Blas, T.; Patinec, V.; Tripier, R.; Tircsó, G.; Carniato, F.; Botta, M.; PlatasIglesias, C. Definition of the Labile Capping Bond Effect in Lanthanide Complexes. Chem. - A Eur. J. 2017, 23, 1110-1117.

Zhang, J.; Heinz, N.; Dolg, M. Understanding
Lanthanoid(III) Hydration Structure and Kinetics by Insights from Energies and Wave Functions. Inorg. Chem. 2014, 53, 7700-7708.

Zhang, J.; Dolg, M. Labile Capping Bonds in Lanthanide(III) Complexes: Shorter and Weaker. J. Phys. Chem. A 2015, 119, 774-780.

Le Fur, M.; Beyler, M.; Molnár, E.; Fougère, O.; Esteban-Gómez, D.; Tircsó, G.; Platas-Iglesias, C.; Lepareur, N.; Rousseaux, O.; Tripier, R. The Role of the Capping Bond Effect on Pyclen ${ }^{N a t} \mathrm{Y}^{3+} /{ }^{90} \mathrm{Y}^{3+}$ Chelates: Full Control of the Regiospecific $N$-Functionalization Makes the Difference. Chem. Commun. 2017, 53, 9534 9537.

Le Fur, M.; Molnár, E.; Beyler, M.; Kálmán, F. K.; Fougère, O.; Esteban-Gómez, D.; Rousseaux, O.; Tripier, R.; Tircsó, G.; Platas-Iglesias, C. A Coordination Chemistry Approach to Fine-Tune the Physicochemical Parameters of Lanthanide Complexes Relevant to Medical Applications. Chem. - A Eur. J. 2018, 24, 3127 3131 .

Chaves, S.; Delgado, R.; Da Silva, J. J. R. F. The Stability of the Metal Complexes of Cyclic Tetra-Aza Tetra-Acetic Acids. Talanta 1992, 39, 249-254.

(a) Rodríguez-Rodríguez, A.; Garda, Z.; Ruscsák, E.; Esteban-Gómez, D.; De Blas, A.; Rodríguez-Blas, T.; Lima, L. M. P.; Beyler, M.; Tripier, R.; Tircsó, G.; Platas-Iglesias, C. Stable $\mathrm{Mn}^{2+}, \mathrm{Cu}^{2+}$ and $\mathrm{Ln}^{3+}$ Complexes with Cyclen-Based Ligands Functionalized with Picolinate Pendant Arms. Dalton Trans. 2015, 44, 5017-5031. (b) Desreux, J. F.; Merciny, E.; Loncin, M. F. Nuclear Magnetic Resonance and Potentiometric Studies of the Protonation Scheme of Two Tetraaza Tetraacetic Macrocycles. Inorg. Chem. 1981, 20, 987-991. (c) Leugger, A. P.; Hertli, L.; Kaden, T. A. Metal Complexes with Macrocyclic Ligands. XI. Ring Size Effect on the Complexation Rates with Transition Metal Ions. Helv. Chim. Acta 1978, 61, 2296-2306.

Takács, A.; Napolitano, R.; Purgel, M.; Bényei, A. C.; Zékány, L.; Brücher, E.; Tóth, I.; Baranyai, Z.; Aime, S. Solution Structures, Stabilities, Kinetics, and Dynamics of DO3A and DO3A-Sulphonamide Complexes. Inorg. Chem. 2014, 53, 2858-2872.

Riesen, A.; Zehnder, M.; Kaden, T. A. Metal Complexes of Macrocyclic Ligands. Part XXIII. Synthesis, Properties, and Structures of Mononuclear Complexes with 12- and 14-Membered Tetraazamacrocycle$N, N^{\prime}, N^{\prime \prime}, N^{\prime \prime \prime}-$ Tetraacetic Acids. Helv. Chim. Acta 1986, 69, 2067-2073.

Regueiro-Figueroa, M.; Ruscsák, E.; Fra, L.; Tircsó, G.; Tóth, I.; de Blas, A.; Rodríguez-Blas, T.; Platas-Iglesias, C.; Esteban-Gómez, D. Highly Stable Complexes of Divalent Metal Ions $\left(\mathrm{Mg}^{2+}, \mathrm{Ca}^{2+}, \mathrm{Cu}^{2+}, \mathrm{Zn}^{2+}, \mathrm{Cd}^{2+}\right.$, and $\mathrm{Pb}^{2+}$ ) with a Dota-Like Ligand Containing a Picolinate Pendant. Eur. J. Inorg. Chem. 2014, 2014, 6165-6173.

Delgado, R.; da Silva, J. J. R. F. Metal Complexes of Cyclic Tetra-Azatetra-Acetic Acids. Talanta 1982, 29, 815-822. 
Thompson, A. L.; Parker, D.; Fulton, D. A.; Howard, J. A. K.; Pandya, S. U.; Puschmann, H.; Senanayake, K.; Stenson, P. A.; Badari, A.; Botta, M.; Avedano, S.; Aime, S. On the Role of the Counter-Ion in Defining Water Structure and Dynamics: Order, Structure and Dynamics in Hydrophilic and Hydrophobic Gadolinium Salt Complexes. Dalton Trans. 2006, 5605-5616.

(37) Powell, D. H.; Ni Dhubhghaill, O. M.; Pubanz, D.; Helm, L.; Lebedev, Y. S.; Schlaepfer, W.; Merbach, A. E. Structural and Dynamic Parameters Obtained from ${ }^{17} \mathrm{O}$ NMR, EPR, and NMRD Studies of Monomeric and Dimeric $\mathrm{Gd}^{3+}$ Complexes of Interest in Magnetic Resonance Imaging: An Integrated and Theoretically Self-Consistent Approach. J. Am. Chem. Soc. 1996, 118, 9333-9346.

(38) Cacheris, W. P.; Nickle, S. K.; Sherry, A. D. Thermodynamic Study of Lanthanide Complexes of 1,4,7-Triazacyclononane- $N, N^{\prime}, N^{\prime \prime}$-Triacetic Acid and $1,4,7,10$-Tetraazacyclododecane- $N, N^{\prime}, N^{\prime \prime}, N^{\prime \prime}$-Tetraacetic Acid. Inorg. Chem. 1987, 26, 958-960.

Kumar, K.; Chang, C. A.; Francesconi, L. C.; Dischino, D. D.; Malley, M. F.; Gougoutas, J. Z.; Tweedle, M. F. Synthesis, Stability, and Structure of Gadolinium(III) and Yttrium(III) Macrocyclic Poly(Amino Carboxylates). Inorg. Chem. 1994, 33, 3567-3575.

(40) Regueiro-Figueroa, M.; Esteban-Gómez, D.; De Blas, A.; Rodríguez-Blas, T.; Platas-Iglesias, C. Understanding Stability Trends along the Lanthanide Series. Chem. - A Eur. J. 2014, 20, 3974-3981.

(41) Sarka, L.; Banyai, I.; Brucher, E.; Kiraly, R.; Platzek, J.; Raduchel, B.; Schmitt-Willich, H. Synthesis, Equilibrium and NMR Studies of Lanthanide(III) Complexes of the $N$-Mono(methylamide) and $N$-Mono(methylamide) Derivatives of Diethylenetriamine- $N, N, N, N^{\prime \prime}, N^{\prime \prime}-$ pentaacetic Acid. J. Chem. Soc. Dalton Trans. 2000, 3699-3703.

(42) Roca-Sabio, A.; Mato-Iglesias, M.; Esteban-Gómez, D.; Toth, É.; De Bias, A.; Platas-Iglesias, C.; RodríguezBlas, T. Macrocyclic Receptor Exhibiting Unprecedented Selectivity for Light Lanthanides. J. Am. Chem. Soc. 2009, 131, 3331-3341.

(43) Gündüz, S.; Vibhute, S.; Botár, R.; Kálmán, F. K.; Tóth, I.; Tircsó, G.; Regueiro-Figueroa, M.; Esteban-Gómez, D.; Platas-Iglesias, C.; Angelovski, G. Coordination Properties of GdDO3A-Based Model Compounds of Bioresponsive MRI Contrast Agents. Inorg. Chem. 2018, 57, 5973-5986.

(44) Baranyai, Z.; Rolla, G, A.; Negri, R.; Forgács, A.; Giovenzana, G. B.; Tei, L. Comprehensive Evaluation of the Physicochemical Properties of $\mathrm{Ln}^{\mathrm{III}}$ Complexes of Aminoethyl-DO3A as pH-Responsive $T_{1}$-MRI Contrast Agents. Chem. - A Eur. J. 2014, 20, 2933-2944.

(45) Wang, X.; Jin, T.; Comblin, V.; Lopez-Mut, A.; Merciny, E.; Desreux, J. F. A Kinetic Investigation of the Lanthanide DOTA Chelates. Stability and Rates of Formation and of Dissociation of a Macrocyclic Gadolinium(III) Polyaza Polycarboxylic MRI Contrast
Agent. Inorg. Chem. 1992, 31, 1095-1099.

Brücher, E.; Laurenczy, G.; Makra, Z. S. Studies on the Kinetics of Formation and Dissociation of the Cerium(III)-DOTA Complex. Inorg. Chim. Acta 1987, $139,141-142$

Ratnakar, S. J.; Woods, M.; Lubag, A. J. M.; Kovács, Z.; Sherry, A. D. Modulation of Water Exchange in Europium(III) DOTA-Tetraamide Complexes via Electronic Substituent Effects. J. Am. Chem. Soc. 2008, $130,6-7$.

(48) Viswanathan, S.; Ratnakar, S. J.; Green, K. N.; Kovacs, Z.; De León-Rodríguez, L. M.; Dean Sherry, A. MultiFrequency PARACEST Agents Based on Europium(III) DOTA-Tetraamide Ligands. Angew. Chem. Int. Ed. 2009, 48, 9330-9333.

(49) Delli Castelli, D.; Tei, L.; Carniato, F.; Aime, S.; Botta, M. [Yb(AAZTA) $\left.\left(\mathrm{H}_{2} \mathrm{O}\right)\right]^{-}$: An Unconventional ParaCEST MRI Probe. Chem. Commun. 2018, 54, 2004-2007.

Funk, A. M.; Finney, K. L. N. A.; Harvey, P.; Kenwright, A. M.; Neil, E. R.; Rogers, N. J.; Kanthi Senanayake, P.; Parker, D. Critical Analysis of the Limitations of Bleaney's Theory of Magnetic Anisotropy in Paramagnetic Lanthanide Coordination Complexes. Chem. Sci. 2015, 6, 1655-1662.

(51) Blackburn, O. A.; Chilton, N. F.; Keller, K.; Tait, C. E.; Myers, W. K.; McInnes, E. J. L.; Kenwright, A. M.; Beer, P. D.; Timmel, C. R.; Faulkner, S. Spectroscopic and Crystal Field Consequences of Fluoride Binding by

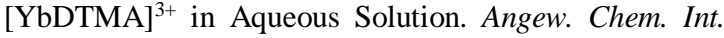
Ed. 2015, 54, 10783-10786.

(52) Do, C.; Alzakhem, N.; Bischof, C.; Wahsner, J.; Gu, T.; Lu, J.; Platas-Iglesias, C.; Seitz, M. Understanding the Quenching Effects of Aromatic C-H- and C-DOscillators in Near-IR Lanthanoid Luminescence. J. Am. Chem. Soc. 2012, 134, 16413-16423.

(53) Zaiss, M.; Angelovski, G.; Demetriou, E.; McMahon, M. T.; Golay, X.; Scheffler, K. QUESP and QUEST Revisited - Fast and Accurate Quantitative CEST Experiments. Magn. Reson. Med. 2018, 79, 1708-1721.

Baranyai, Z.; Delli Castelli, D.; Platas-Iglesias, C.; Esteban-Gomez, D.; Bényei, A.; Tei, L.; Botta, M. Combined NMR, DFT and X-Ray Studies Highlight Structural and Hydration Changes of $[\operatorname{Ln}(\text { AAZTA })]^{-}$ Complexes across the Series. Inorg. Chem. Front. 2020, 7, 795-803.

(55) Regueiro-Figueroa, M.; Platas-Iglesias, C. Toward the Prediction of Water Exchange Rates in Magnetic Resonance Imaging Contrast Agents: A Density Functional Theory Study. J. Phys. Chem. A 2015, 119, 6436-6445.

(56) Esteban-Gómez, D.; de Blas, A.; Rodríguez-Blas, T.; Helm, L.; Platas-Iglesias, C. Hyperfine Coupling Constants on Inner-Sphere Water Molecules of Gd(III)Based MRI Contrast Agents. ChemPhysChem 2012, 13, 3640-3650. 

Contraction Revisited. J. Am. Chem. Soc. 2007, 129, 11153-11160.

(58) Kerridge, A. Quantification of F-Element Covalency through Analysis of the Electron Density: Insights from Simulation. Chem. Commun. 2017, 53, 6685-6695.

(59) Wu, Q.-Y.; Cheng, Z.-P.; Lan, J.-H.; Wang, C.-Z.; Chai, Z.-F.; Gibson, J. K.; Shi, W.-Q. Insight into the Nature of $\mathrm{M}-\mathrm{C}$ Bonding in the Lanthanide/Actinide-Biscarbene Complexes: A Theoretical Perspective. Dalton Trans. 2018, 47, 12718-12725.

(60) Irving, H. M.; Miles, M. G.; Pettit, L. D. A Study of Some Problems in Determining the Stoicheiometric Proton Dissociation Constants of Complexes by Potentiometric Titrations Using a Glass Electrode. Anal. Chim. Acta 1967, 38, 475-488.

(61) Zekany, L.; Nagypal, I. PSEQUAD. In Computational Methods for the Determination of Formation Constants $S E$ - 8; Leggett, D., Ed.; Modern Inorganic Chemistry; Springer US, 1985; pp 291-353.

(62) Tao, J.; Perdew, J. P.; Staroverov, V. N.; Scuseria, G. E. Climbing the Density Functional Ladder: Nonempirical Meta-Generalized Gradient Approximation Designed for Molecules and Solids. Phys. Rev. Lett. 2003, 91, 146401.

(63) Gaussian 09, Revision E.01, Frisch, M. J.; Trucks, G. W.; Schlegel, H. B.; Scuseria, G. E.; Robb, M. A.; Cheeseman, J. R.; Scalmani, G.; Barone, V.; Mennucci,
B.; Petersson, G. A.; Nakatsuji, H.; Caricato, M.; Li, X.; Hratchian, H. P.; Izmaylov, A. F.; Bloino, J.; Zheng, G.; Sonnenberg, J. L.; Hada, M.; Ehara, M.; Toyota, K.; Fukuda, R.; Hasegawa, J.; Ishida, M.; Nakajima, T.; Honda, Y.; Kitao, O.; Nakai, H.; Vreven, T.; Montgomery, Jr., J. A.; Peralta, J. E.; Ogliaro, F.; Bearpark, M.; Heyd, J. J.; Brothers, E.; Kudin, K. N.; Staroverov, V. N.; Kobayashi, R.; Normand, J.; Raghavachari, K.; Rendell, A.; Burant, J. C.; Iyengar, S. S.; Tomasi, J.; Cossi, M.; Rega, N.; Millam, N. J.; Klene, M.; Knox, J. E.; Cross, J. B.; Bakken, V.; Adamo, C.; Jaramillo, J.; Gomperts, R.; Stratmann, R. E.; Yazyev, O.; Austin, A. J.; Cammi, R.; Pomelli, C.; Ochterski, J. W.; Martin, R. L.; Morokuma, K.; Zakrzewski, V. G.; Voth, G. A.; Salvador, P.; Dannenberg, J. J.; Dapprich, S.; Daniels, A. D.; Farkas, Ö.; Foresman, J. B.; Ortiz, J. V.; Cioslowski, J.; Fox, D. J. Gaussian, Inc., Wallingford CT, 2009.

(64) Dolg, M.; Stoll, H.; Savin, A.; Preuss, H. EnergyAdjusted Pseudopotentials for the Rare Earth Elements. Theor. Chim. Acta 1989, 75, 173-194.

(65) Tomasi, J.; Mennucci, B.; Cammi, R. Quantum Mechanical Continuum Solvation Models. Chem. Rev. 2005, 105, 2999-3093.

(66) Lu, T.; Chen, F. Multiwfn: A Multifunctional Wavefunction Analyzer. J. Comput. Chem. 2012, 33, 580-592. 


\section{TOC Graphic:}

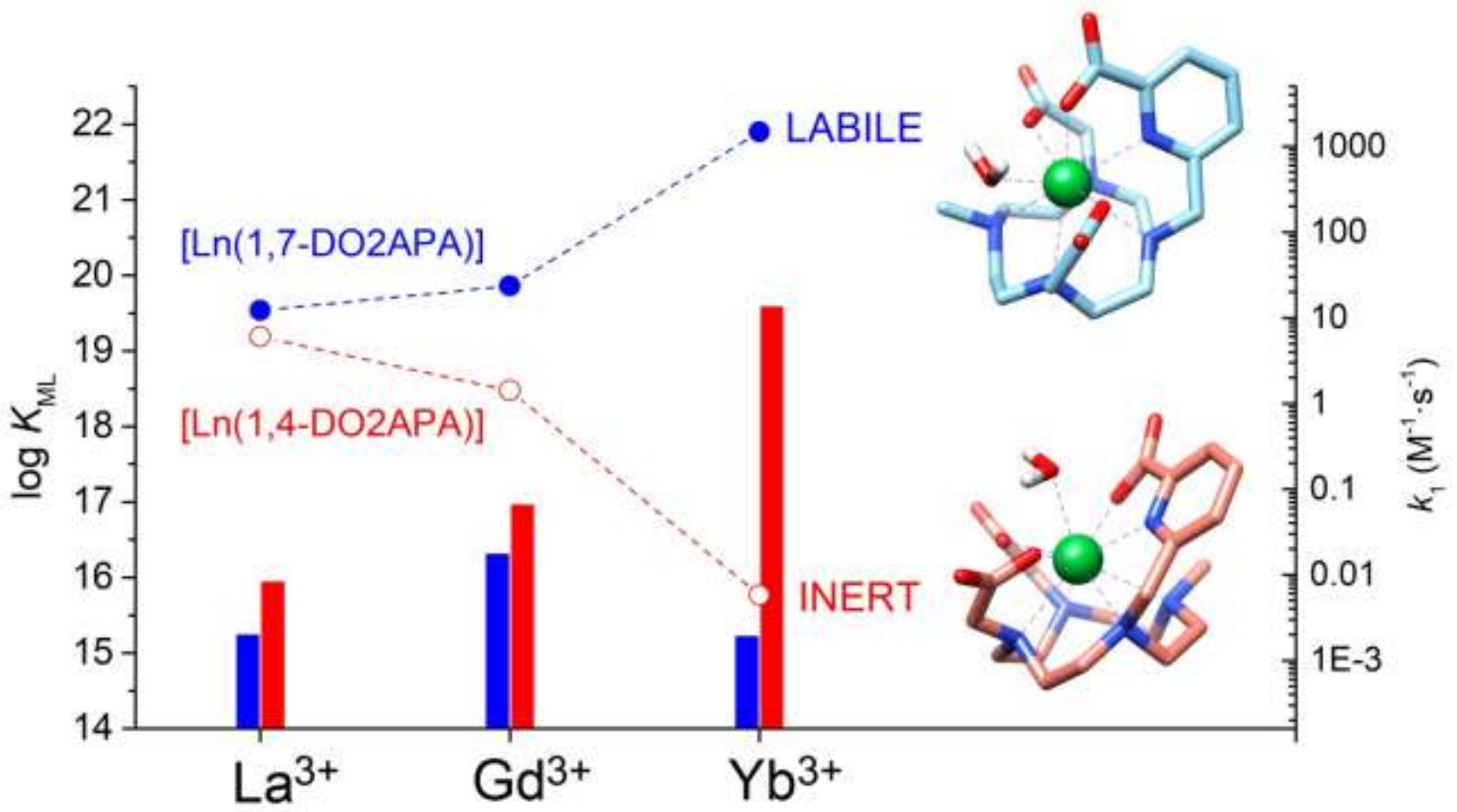

The arrangement of the ligand donor atoms around the lanthanide ion provokes dramatic differences in the thermodynamic stabilities and dissociation kinetics of lanthanide complexes, as demonstrated by investigating the complexes with two isomeric cyclen-based ligands, containing a picolinate arm and two acetate arms either in positions 1,7 or 1,4 of the macrocyclic structure. 